\title{
ŞEYH HAMZA TEKKESI'NIN SOSYO-EKONOMİK VE KÜLTÜREL TARİHİ
}

Zekeriya IŞIK ${ }^{1}$

Atıf/O: Işık, Z. (2020). Şeyh Hamza Tekkesi'nin sosyo-ekonomik ve kültürel tarihi. Hitit Üniversitesi Sosyal Bilimler Enstitüsü Dergisi, 13(1), 106-129. doi: 10.17218.hititsosbil.694093

Özet: Şeyh Hamza ne zaman yaşadığı tam olarak bilinmeyen, Çorum’un Hacı Bey Ağacı köyünde medfun bulunan ancak mezarının yeri zamanla kaybolan dinî, manevi hüviyete sahip tarihi bir şahsiyettir. Şeyh Hamza'nın mezarı, arşiv vesikalarında geçtiği şekliyle Çorum'da ikamet eden Derviş Hıdır’ın onu rüyasında görmesi sonucu bqulunmuştur. Bulunan mezarın üzerine Derviş Hıdır ile ahalinin yardım ve gayretiyle türbe yanına da bir tekke inşa edilmiştir. İlk örneklerine nazaran hayli geç bir dönemde (18. yüzyıl ortalarında) ortaya çıktığ1 anlaşılan tekkenin resmen tanınması ve sisteme eklemlenmesi de hayli zaman almıştır. Tekkenin kamusal alanda karşılık bulmasında Çorum-Laçin-Osmancık güzergahı üzerinde yer alması ve bu bölgede benzeri hizmet verecek başkaca bir zaviyenin bulunmamasının etkisi büyük olmuştur. Şeyh Hamza tekkesi erken dönem örnekleri gibi zengin vakıf gelirlerine ulaşamadığından sosyo-ekonomik yapısı nispeten zayıf kalmıştır. Bugün tarihi yapılardan eser kalmamakla birlikte yeniden inşa edilen türbe ve mescit köyün dinî, sosyal, kültürel yaşantısında etkin rol oynamaya devam etmektedir. İşte bu çalışma Şeyh Hamza türbesi ve tekkesinin idari, sosyal, ekonomik yapısını ortaya koymak, zamanında toplum üzerindeki etkilerini araştırmak amacıyla yapılmıştır.

Anahtar Kelimeler: Osmanl, Tarikat, Tekke, Türbe, Şeyh Hamza.

\section{The Socio-Economic and Cultural History of Sheikh Hamza Dervish Lodge}

Citation/@: Surname, First Letter of Name. (2020). The socio-economic and cultural history of Sheikh Hamza Dervish Lodge. Hitit University Journal of Social Sciences Institute, 13(1), 106-129. doi: 10.17218.hititsosbil.694093

Abstract: Sheikh Hamza is a historic figure with a religious and spiritual identity. It is not known when he has lived but his burial site was found in Hacı Bey Ağac1 village of Çorum, which was then forgotten over time. According to archives, the grave of Sheikh Hamza was found following a divine intervention. It was revealed during a dream to Dervish Hıdır residing in Çorum. With the help of the locals, Dervish Hidir built a shrine and a lodge at the burial site. Compared to initial samples, this monastery revealed at later stages, during mid-18th century and its official recognition and addition into the system also took a great while. The reason for the monastery to gain popularity among the public was its location on the Çorum-Laçin-Osmancık routewhich does not include any other similar structures providing the same service. Unlike the early-age examples, Sheik Hamza monastery failed to gain rich foundation revenues and therefore its socio-economic structure was relatively weak. The historic structures are now all gone but the re-built shrine and masjid is still playing an important role in serving the religious, social and cultural lives of the locals. The purpose of this study is to reveal the administrative, social and economic structure of Sheikh Hamza shrine and lodge, and to understand the impact on society's faith and minds.

Keywords: Ottomans, Sect, Lodge, Shrine, Sheikh Hamza.

Makale Geliş Tarihi: 25.2.2020 Makale Kabul Tarihi: 21.6.2020

${ }^{1}$ Doç. Dr., Hitit Üniversitesi, FEF, Tarih Bölümü, zekeriyaisik@hitit.edu.tr, http://orcid.org/0000-0003-3528-902X 


\section{GİRIŞ}

Şeyh Hamza'nın yaşadığı ve medfun bulunduğu Çorum'un tarihi antik dönemlere kadar gitmekle birlikte ne zaman fethedildiği kesin olarak bilinmemektedir. Şehrin Büyük Selçuklu Sultanı Melikşah'ın emirlerinden Emir Tutak ile Emir Artuk ya da 1071 Malazgirt zaferi sonrası Danişmentli Ahmet Gazi tarafından mı fethedildiği hususu tartışmalıdır (Bakırer, 2015, ss.58-59; Tonbuş, 1940, s.657). Danişmentlilerin (1071-1178) Çorum, Çankırı, Yozgat, Ankara ve Kastamonu yöresini hâkimiyet altına aldığı hatta Çorum'un I. (1097) ve II. Haçlı (1101) seferleri esnasında Danişmentlilerle Haçlılar arasındaki mücadelede bir tampon bölge vazifesi gördüğü kaydedilmiştir (Korkmaz, 2003, s.20). Bu dönemde Türkmen aşiretlerinin yoğun göçüne maruz kaldığı anlaşılan Çorum, Anadolu Selçuklularıyla Danişmentliler arasında birçok kez el değiştirmesine rağmen uzun süre Danişmentlilerin hâkimiyetinde kalmıştır (Şahin, 1993, s.374).

Anadolu Selçuklu devletinin Babaî isyanının ağır sonuçlarıyla zayıf kalmasını Kösedağ Savaşı yenilgisi sonrası Moğol istilası izlemiş, Moğollar göçebe Türkmen aşiretleri tarafından daha çok otlak ve yurtluk olarak kullanılan Çorum havalisini istila etmişlerdir (Şahin, 1993, s.374). Anadolu'da Moğol hâkimiyetinin zayıflamasıyla birlikte bölge önce Eratnaoğulları sonra 1360'larda da Amasya'da bulunan Emir Hacı Şadgeldi'nin idaresine girmiştir. Çorum 1392'de Osmanlılar ile Kadı Burhanettin arasında yapılan Kırkdilim savaşına sahne olmuş, savaşı kazanan Kadı Burhaneddin bölgeye hâkim olmuştur. Akkoyunlu beyi Karayülük Osman'ın 1398'de Kad1 Burhaneddin beyliğini ortadan kaldırması (Bulduk, 1992, s.130; Şahin, 1993, s.374-375) ve Rum beylerbeyi Yörgüç Paşa'nın 1427 tarihlerinde yerel beylikleri otorite altına almasıyla Çorum nihai olarak Osmanlı hâkimiyetine girmiştir (Bakırer, 2015, s.58; Öz, 1991, s.5).

Aslında Çorum'un yaşadığı bu girift siyasi ve askeri mücadelelerle dolu tarihi süreç bölgenin Türkmen iskânıyla yer ve yurt tutulması hadisesinin ne denli çetin şartlar altında ve uzunca bir zaman diliminde olduğuna da işaret etmektedir. Nitekim Anadolu'nun Türkleşip İslamlaşmasında başat rol oynayan erken dönem Türkmen babaları, şeyh ve derviş gruplarının Çorum havalisinde etkin olarak 13. yüzyıl sonları 14. yüzyıl başlarında, bölgenin fethine nazaran biraz geç bir dönemde belirmiş olmaları da bu durumun bir göstergesi olmalıdır. Çorum havalisinde bölgenin demografik yapısını Türkmenlerden yana değiştiren büyük iskân organizasyonunun söz konusu erken dönem Türkmen babaları ve dervişlerinin sevk ve idaresinde onlar tarafından kurulan tekke ve zaviyelerin maddi ve manevi silueti etrafında şekillendiği söylenebilir (Barkan, 1942, s.280300). Öyle ki, bu tarihsel süreçte bütün Anadolu'da siyasi, askeri, sosyal ve içtimai hayatın merkezinde yer aldıkları anlaşılan bu tasavvufi şahsiyetler, öldükten sonra da bu mekânlarda bulunan kabirlerinin bir ziyaretgâha dönüşmesiyle(Erginli, 2002, s. 107) derviş grupları ve Türkmenler üzerinde manevi, birleştirici bir unsur olmayı sürdürmüşlerdir. Aşıkpaşazâdenin dönemin sosyal ve içtimai hayatına yön veren zümreleri sayarken zikrettiği Ahiler, Abdallar ve Bacıların da tasavvuf meşrep olmaları bu bağlamda son derece anlamlıdır(Âşık Paşazâde, 2003, s. 571).

Söz konusu dönemde Çorum ve civarında Baba İlyas-1 Horasânî'nin dip torunu Elvan Çelebi (ö. 1358-59 veya sonras1), Veysel Karani soyundan gelen Şeyh Zeynüddin ve halifesi Piri Baba (vakfiyesi H. 768 (M. 1366-67), Seyyid Murat (vakfiyesi H. 769/M. 1367-68) tarih sahnesine çıkarak kurdukları tekke ve zaviyeleriyle etkili oldukları görülmektedir. ${ }^{1}$ Orta zamanlar diyebileceğimiz 15 ve 16. yüzyıllarda ise bir Kalenderi dervişi olan Abdal Ata (vakfiyesi H. 822/M. 1419), Hasan Balım Sultan yine faaliyetleri ve zaviyeleriyle ön plana çıkmışlardır (Çanak Erten, 2013, ss.20-21; Iş1k, 2018, ss.321-323). 
Tekke ve zaviyelerin özellikle 16 ila 18. yüzyıllar arasında imparatorluk sathına yayıldığı görülmektedir (Işık, 2015, s. 33-34). Devlet, ulaşım ve iletişim sağlamanın çok güç, güvenlik problemlerini halletme maliyetlerinin yüksek, fütuhatı kalıc1 ve sürekli kılacak lojistik kaynakların sınırlı, iskân organizasyonlarının sevk ve idaresinin zor, atıl toprakların şen ve abat kılınmasının başlıca problem olduğu bir dönemde tekke, zaviye ve dergâhları işe koşmuştur(Karaca ve Karaboğa, 2019, s. 1587). Hatta bütün bu kamusal hizmetleri karş1lı̆ında devlet, onlar lehine bir takım toprak gelirlerinden feragat ettiği gibi başta sultanlar olmak üzere devlet ricali de tekke, zaviye ve türbe giderleri için vakıflar kurmuşlardır(Özdemir, 1994, ss. 267268-290).

İşte Şeyh Hamza tekkesinin tarih sahnesine çıktığı dönem tarikatlar açısından sözü edilen çok yönlü işlevlerden bazılarının kaybedildiği bazılarının da giderek el değiștireceği Osmanlı modernleşme sürecinin hemen arifesine denk düşmektedir. ${ }^{2}$ Nitekim Osmanlı fütuhatının duraksamasıyla birlikte tarikatlar, fütuhat ve iskâna dair üstlendikleri hayati fonksiyonları büyük ölçüde kaybetmişlerdir. ${ }^{3}$ Ancak 18. yüzyıl sonlarında tekke ve zaviyeler imparatorluğun hala ulaşım ve haberleşme ağının sağlıklı bir şekilde işletilmesinde, yer yer tekin olmayan beldelerde güvenliğin sağlanmasında ve bulundukları yerlerde toplumun dinî, manevi, sosyal ve kültürel alanlarda bir takım ihtiyaçlarının karşılanmasında önemli bir yere sahipti. Bütün bu mülahazalara göre Şeyh Hamza tekkesi gelenekselleşen Osmanlı tekke örgüsü içinde doğmuş ancak hayatiyetini din ve dinî kurumlar için önemli değişikliklere yol açacak olan reform çağında sürdürmek zorunda kalmıştır. Dolayısıyla Şeyh Hamza Tekkesi ile ilgili değerlendirmelerde bulunurken gerek Çorum havalisindeki tekke ve tarikat anlayışının tarihsel gelişim süreci gerekse tarikatların, tekke ve zaviyelerin zamanla değişen anlam ve mahiyeti mutlaka göz önünde bulundurulmalidir.

\subsection{Amaç ve Yöntem}

Bu çalışma 18. yüzyılın ortalarında Çorum havalisinde Çorum-Laçin-Osmancık yol güzergahı üzerinde Hacı Bey Ağacı köyünde kurulduğu anlaşılan Şeyh Hamza Tekkesi'nin idari, sosyal, ekonomik ve kültürel tarihini ortaya koymak, bölgede devlet ve toplum üzerindeki etkilerini, üstlendiği misyonları anlamak ve anlamlandırmak amacıyla yapılmıştır. Gerek tekkenin ortaya çıktığı dönemden kaynaklanan ve tekkenin inşasına, mimari dokusuna, irşat faaliyetlerine de yön veren sosyal, ekonomik ve kültürel unsurlar gerekse kurulduğu coğrafyanın sosyal ve fiziki özelliklerinden kaynaklı hususlar göz önünde bulundurulmak suretiyle Şeyh Hamza türbe ve tekkesinin tarihteki yeri ve önemi anlaşılmaya çalışılmıştır.

Konu oldukça dar, spesifik olduğundan ve tarihi kaynaklarda hakkında yeterince bilgi bulunmadığından daha çok arşiv verilerinden yararlanılma yoluna gidilmisstir. Zaviyenin bulunduğu yerin fiziki özelliklerini, sosyal, demografik ve kültürel dokusunu anlamak amaciyla da yerinde de araştırmalar yapılmıştır.

\section{HACI BEY AĞACI (ŞEYH HAMZA) KÖYÜ}

Şeyh Hamza köyü kuzey doğu yönünde Çorum’a 22,7 km uzaklıkta Çorum-Laçin-Osmancık yol güzergahı üzerinde, Kösedağ’n eteğinde dağlık bir arazi üzerinde bulunmaktadır (Ali İzzet Efendi 1997, s. 106). Taşpınar, Feruz, Çatak, Soğuksu, Ayas, Türkler biraz ilerisinde Kırkdilim, Çalyayla (eski adı Sarin) köyleri ile aynı bölgededir. Çatak ile Şeyh Hamza köyleri arasındaki arazi parçasına halk arasında Alanyudlu da denilmektedir (Köseoğlu, 2009, s. 1280). Köyün kuzey tarafı ise dağlıktır. Köyün batısında halk dilinde Ağcakise mevkii olarak adlandırılan yerde Bizans döneminden kalma Ağca/Akça Kilise denilen eski harabe bir yerleşim yerinin bulunduğu belirtilmiştir. Yine buralarda yer yer Bizans dönemine ait madeni paralara, antik çağlara ait taşlar 
ve küp şeklinde mezarlara rastlanıldığının kaydedilmesi bölgenin farklı medeniyetlere beşiklik etmiş çok eski bir yerleşim yeri olduğunu göstermektedir (Köseoğlu, 2009, ss.488-489).

Şeyh Hamza köyü, M. 1530 tarihli tahrir kayıtlarında Hacı Bey Ağacı olarak geçmekte 12 hanesi olan karyenin nüfusunun yaklaşık 60 olduğu tahmin edilmektedir (Erkoç, 2015, s.326). Çorum kazası mufassal defterlerinde de (M. 1576/1577) aynı isimle kaydedilmiş bulunan köyde 2 nim, 3 bennak, 19 caba, 14 mücerred olmak üzere toplam 38 vergi mükellefi vardır ve köy Enam (İnam) Çelebi Zaviyesinin vakfı olarak görülmektedir. Köyde en fazla nim çift vergi mükellefinin olması ve köyde yetişen bütün ürünlerden alınan vergiler ve harçlardan oluşan yıllık gelirin 1500 akçe yekûn tutması köyün geneli itibari ile ekonomik ve iktisadi yapısının zayıf olduğunu göstermektedir. Köyden toplanan resimler arasında hınta (buğday) (420), şâ̂r (arpa) (250) gelirleri diğerlerine oranla çok yüksek olmakla birlikte ceviz (10), piyaz (20), meyve (59) gibi farklı ürünlerin de yetiştirildiği anlaşılmaktadır. Yine kayıtlarda geçen ağnam (50) vergisinden hayvancılık yapıldığı, küvvare (20) vergisinden de arıcılıkla uğraşıldığı görülmektedir (Defter-i Mufassal-1 Liva-i Çorum, 2014, s.123). 19. Yüzyıl ortalarında temettuat defterlerinde bulunan kayıtlara göre de Şey Hamza Köyü'nün 1846 yılı vergileri toplamı 2508 kuruştur ki bu miktar da düşüktür (ML. VRD. TMT.d. 521, H. 29.Zilhicce 1262/M. 18 Aralık 1846). Köyün zirai ürünler bakımından gelirlerinin azlığında yerinde yapılan saha çalışmalarında da görüldüğü üzere tarım yapılabilecek arazinin sınırlılığı ile toprak yapısının kireçli olmasının rolü büyüktür.

Hacı Bey Ağacı Köyü'nün adının Hicri 12 Rebîülevvel 1204 (M. 30 Kasım 1789) tarihinden evvel Şeyh Hamza'nın mezarının tespiti ile üzerine bir türbe ve tekke yapılması ardından zamanla değiştiği ve Şeyh Hamza olarak anılmaya ve resmi kayıtlarda da bu şekilde geçmeye başladiğ anlaş1lmaktadır (C.EV. Nr. 21-1003). Köyün ismi, resmi kayıtlarda H. 29 Zilhicce 1231'de (M. 20 Kasım 1816) hala Hacı Bey Ağacı olarak geçerken nihayet Hicri 29 Zilhicce 1262 (M. 18 Aralık 1846) tarihli temettuat defterlerinde Şeyh Hamza olarak değiştiği görülmektedir.

1837 tarihli Osmanlı nüfus sayımı sonuçlarına göre tanzim edilen 1917 numaralı nüfus defterlerinde köyde 34 erkek nüfus bulunurken (Şahin, 2017, ss.372-373) 1846 temettuat defterlerine göre de 10 hanede toplam 62 kişinin yaşadığ1 görülmektedir (ML. VRD. TMT.d. Nr. 521/2). Bu kayıtlara göre köy halkı Hıdırbeyoğlu, Topuzoğlu, Dalyanoğlu, Gökoğlu, Cinalioğlu, Kuyrukçuoğlu namıyla anılan sülalelerden oluşmaktadır (ML. VRD. TMT.d. Nr. 521/2).

\section{3. ŞEYH HAMZA'NIN MEZARININ BULUNMASI VE TÜRBE İLE TEKKENİN İNŞA SÜRECİ}

Hacı Bey Ağacı köyünün 1576-77 tarihli tahrir defterlerinde Enam (İnam) Çelebi Zaviyesi'nin vakfı olması, ilerleyen dönemlerde Şeyh Hamza mezrası hasılatından Osmancık'ta bulunan Gazi Ferahşat Camiî vakfına gelir ayrılması, ${ }^{4}$ sayılan vergi mükellefleri arasında köyde derviş bulunmaması (Defter-i Mufassal-1 Liva-i Çorum, 2014, s.123), yine tahrir kayıtlarında geçen kişi adları arasında Şeyh Hamza'nın isminin geçmemesi, ${ }^{5}$ adına türbe ve tekke ihdas edilen bu tarihi şahsiyetin en azından bu tarihlerden sonra yaşamış olabileceğini göstermesi bakımından önemlidir.

Burada Şeyh Hamza'nın mezarının bulunması hadisesinin ne zaman olduğu hususu da ayrıca bir sorun olarak karşımızda durmaktadır. Şeyh Hamza'nın türbe ve tekkesinden bahseden eldeki en eski belge Hicri 12 Rebîülevvel 1204 (M. 30 Kasım 1789) tarihli olduğuna göre mezarın keşfi ile türbe ve tekkenin inşası bu tarihten önce olmalıdır. Ayrıca bu hususta Şeyh Hamza'y1 rüyasında gördüğünü ileri sürerek sürecin başlamasına vesile olan Derviş Hıdır'ın 1819'da Şeyh Hamza türbesi türbedarlığı ile tekke meşihatının kendisine tevcihi için talepte bulunmasından 
yola çıkıldığında (C. EV. 512/25898, 1-2) bu keşif 18. yüzyılın üçüncü çeyreğinde ya da en geç dördüncü çeyreğin başlarında vukuu bulmuştur denilebilir. ${ }^{6}$

Şeyh Hamza'nın hayatına dair elimizdeki bilgiler ise yok denecek kadar azdır. O dönemde köyde ve civarda yaşayan insanların Şeyh Hamza'yı bir veli şahsiyet olarak hafizalarında tutmakla birlikte mezarının yeri hakkında "Şeyh Hamza ismiyle müsemma bir azizin medfûn idüğü sicil-i mahfûzda mukayyed ve beynel ahali mütearif ve meşhûr olub ancak aziz-i müşârün-ileyhin karyei mezbûre derûnunda merkad-ı şerifinde bir eser olmadiğından başka etraf-ı kurra ahalilerinden dahi bilür kimesne olmadiğına binaen medfeni na-ma'lûm iken..." (C. EV. 280/14279/1 (20 Rebîulevvel 1234/M. 17 Ocak 1819) görüldüğü üzere bilgilerinin bulunmamasina, 1576-77 tarihli tahrir kayitlarında adına ve izine rastlanmamasına bakılırsa Şeyh Hamza, mezarının bulunmasından uzunca bir süre önce (en erken 16. yüzyıl sonları veya 17. yüzyılda) yaşamış olmalıdır. Yani Şeyh Hamza halkın zihninde ve gönül dünyasında menkıbeleriyle yaşamakla birlikte zamanla mezarı kaybolmuştur.

Şeyh Hamza'nın mezarının bulunması ve üzerine türbe ile yanına bir tekkenin yapılması süreci aslında o dönemlerde tarikatların ve onların yaşamlarında çok önemli bir yere sahip olan tasavvufi 1stılahların gerek toplum gerekse kamusal alanda ne denli güçlü bir karşıllk bulduğunu gösteren ilginç bir örnekliğe sahiptir. Zira Şeyhin mezarının bulunmasına ardından türbe ve tekkenin inşasına yol açan hadise, Derviş Hıdır namında Çorum'da ikamet eden bir dervişin gördüğünü belirttiği rüyaya dayanmaktadır. ${ }^{7}$ Başka bir deyişle de tasavvufun ameller ve maneviyat arasında mutlu bir denge kurmadaki mahareti kendisini göstermiş (Bademci 2019, s. 73-74), ilahi bir işaret kabul edilen dervişin rüyası ile hayırlı bir amel olduğuna inanılan bir velinin mezarı üzerine türbe inşası meselesi örtüşmüştür.

Arşiv kayıtlarından anlaşıldığına göre Şeyh Hamza adıyla anılan bir azizin Hacı Bey Ağacı köyünde medfun bulunduğu hem dönemin yerli ahalisi tarafından bilinen hem de kayıtlarda yer alan bir durumdu. Burada asıl mesele Şeyh Hamza'nın medfun bulunduğu kabrin zamanla kaybolması ve civarda konuyu aydınlatacak bir bilirkişinin de olmamasıydı. Şeyh Hamza'nın "merkadı (mezar) na-ma'lûm ve karye-i merkûme ahalisinden bilür kimesne dahi olmaya tahtü'l-turab (yeri, toprağı) gâib ve eser-i ma'dûm (izi, eseri yok)" (HAT. 543/26857/1, H. 29. Zilhicce 1231/M. 20 Kasım 1816) iken Çorum kazası sakinlerinden Derviş Hıdır namında bir sûfi "âlem-i menamında aziz-i müşârün-ileyhi rü'yet” etmiş "benim kabrimi ihraç eyleyü olduğu mahal avânelenmiş̧" olduğu kendisine rüyasında belirtilerek kabrin yeri işaret edilmişstir (C. EV. 280/14279/1, 20 Rebîülevvel 1234/M. 17 Ocak 1819). Derviş Hıdır keyfiyeti cümle ahaliye ilan ederek maiyetine yakınında bulunan dostlarını ve ustaları alarak söz konusu köye gitmiş, kendisine malum edilen yeri kazdıklarında azizin cesedi tamamen zuhur etmiştir (HAT. 543/26857/1).

Tasavvufi bir 1stılahla keşfedilen mezar üzerine hemen bir türbe (Ali İzzet Efendi, 1997, s.105) ve tekke inşasının ahalinin sevabına yaptığı yardımlarla inşa edilmesi tekke ve zaviyelerin kuruluş biçimlerinden birisini ortaya koyması açısından mühimdir. Derviş Hıdır, sûfî kişiliğinin kendisine sağladığı avantajla ahaliyi de işin içine katarak cümlenin sevabıyla "merkadını tanzim ve ihya ve üzerine tekke, bina ve inşa” eylemiştir (HAT. 543/26857/1). Burada Derviş Hıdır'ın sadece yerel ahaliyi değil resmi kurumları da işin içine dâhil ettiğinden şüphe yoktur. Nitekim Osmanlı devletinde türbelerin ve özellikle de tekke ve zaviyelerin toplumsal alanda üstlendikleri çok çeşitli fonksiyonlar göz önüne alındığında böylesi bir külliyenin inşası öncesinde Derviş Hıdır’n Çorum'daki yerel yöneticileri ikna ettiğini en azından gerekli bilgilendirmeleri yaptığını anlamak güç değildir. Şüphesiz bu hususu kanttlayan en önemli gelişme türbe ve tekkenin bu tür kurumlara sağlanan devlet imkânlarına hem de yerel idarecilerin çabalarıyla kavuşmasıdır (C. EV. 280/14279/1, 20 Rebîülevvel 1234/M. 17 Ocak 1819). Böylece Derviş Hıdır’n rüyasıyla 
başlayan süreç, Şeyh Hamza'nın mezarının bulunması, türbe ve tekkenin yapılması ve zamanla resmen sisteme katılarak bu tür kurumlara sağlanan idari, hukuki ve ekonomik avantajlara buranın da dâhil edilmesiyle sonuçlanmıştır.

\section{4. ŞEYH HAMZA TEKKESİ'NİN İDARİ VE SOSYAL-KÜLTÜREL YAPISI}

Şeyh Hamza'nın mezarı bulunmuş, üzerine türbe ve tekke inşa edilmiş olsa da söz konusu müesseselerin Osmanlı devlet teşkilatı içerisinde resmen tanınması ve yer edinmesi o kadar kolay olmamıştır. Yukarıda da izah edilmeye çalışıldığı üzere en geç 18. yüzyılın ortalarını geçerek faaliyette olduğu anlaşılan Şeyh Hamza tekkesi bundan yaklaşık 60-70 yıl sonrasında bile henüz resmi kayıtlarda tam olarak yerini alamamış görünmektedir. Zira "zâviye-i mezkûrun şeyhlik beratı olmadığı", zaviye ve meşihat kaydı bulunmadığı, zaviye ile ilgili muhasebe kayıtlarında, Haremeyn-i Şerifeyn muhasebesinde, mukataasında ve askerî ruznamçelerde de bir kaydına rastlanmadığının kaydedilmesi bu durumu açıkça ortaya koymaktadır (C. EV. 512/25898/1, 5 Rebîülâhir 1234/M. 1 Şubat 1819). Nitekim bir hattı hümayundan tekkenin ihtiyacı olan varidat ile ilgili talebin Çorum Naibi ve Çorum ahalisi tarafından bir arzuhal ile merkezi hükümete bildirilmiş olması da henüz tekke postunun fiilen olmasa bile resmen boş olduğu anlamına gelmektedir (HAT. 543/26857). Derviş Hıdır'ın gönüllü olarak yürüttüğü anlaşılan Şeyh Hamza türbesi türbedarlığı ile tekke meşihatının kendisine tevcihi için 1819'da talepte bulunduğunu gösteren kayıt da bu durumu açıkça göstermektedir (C. EV. 512/25898, 1-2).

Tekke ve zaviyelerin inşasıyla değil ancak bu yapıların resmen tanınması ve kayıtlara geçirilmesiyle yani sisteme adapte edilmesiyle devlet tarafından bir takım tahsisat ve haklara muhatap olabildiğini gösteren bu hadise de problem, gönüllü olarak türbedarlık ve tekke şeyhliği görevlerini yürüten Derviş Hıdır'in resmen atanma talebinin kabulüyle çözülmüş görünmektedir (C. EV. 512/25898/1). Derviş Hıdır'dan sonra postnişinlik görevi yani tekkenin sevk ve idaresi onun soyundan gelen Hıdırbeyoğulları sülalesince sürdürülmüştür (Erkoç, 2015, s.326). Nitekim kayıtlarda Derviş Hıdır'ın oğlu Mehmet'in Şeyh Hamza köyünde yaşadığı, tarım ve hayvancılıkla geçimini sağladığı, İbrahim, Hasan ve Fatma adlarını taşıyan üç çocuğu olduğu ve Hicri 1276 yılında vefat ettiği şeriye sicillerinde geçen tereke kayıtlarından anlaşılmaktadır (Çorum Şeriye Sicilleri, 2009, 75; H. 13 Şaban 1278/M. 13 Şubat 1862).

Derviş Hıdır'in hangi tarikata tabi olduğu, tekkede hangi yol ve erkânın takip edildiği dolayısıyla burada yürütülen faaliyetlerin sosyo-kültürel karakterine dair elimizde bilgi yoktur. Hasluck Bektaşi tekkeleri üzerine yaptığı araştırmada bu tarikata mensup tekke ve zaviyelerin daha çok Alevi veya Şiî Müslümanların yaşadığı bölgelerde kurulduğunu kaydetmiştir (1999, s.21). Buna göre Şeyh Hamza köyüne komşu Alevi köyünün bulunmaması, Alevi köylerinin daha çok Köse dağın diğer tarafında kalması tekkenin en azından Bektaşi geleneğe tabi olmadığı şeklinde yorumlanabilir. Bununla birlikte gerek merkezi örgütlenme gerekse merkezi tekke uygulaması bakımından diğer tarikatlara oranla daha sistemli oldukları görülen Hacı Bektaş Veli ve Mevlana dergâhlarından bu tarikatlara bağlı tekke ve zaviyelerin meşihatına atamalar yapılmasına rağmen Şeyh Hamza tekkesi postuna böylesi bir tevcihin yapıldığına dair elde her hangi bir kayıt da yoktur. Bu durum Çorum kırsalında Bektaşî, merkezinde ise Mevlevî tarikatının varlığı mevcutsa da Derviş Hıdır'ın söz konusu bu tarikatlara mensubiyetinin bulunmadığı şeklinde yorumlanabilir. Ankara, Kastamonu, Sivas Osmanlı vilayet salnamelerinde (1869-1908) Şeyh Hamza türbesi Çorum havalisinde halkın ihtimam gösterdiği ziyaretgâhlar arasında sayılırken şehirde bir Mevlevî, iki Halidî, iki Rifâi toplam üç tarikat koluna tabi beş tekkeden bahsedilmektedir (Çanlı, 2013, s.249). Bu bilgi ve değerlendirmeler 1şı̆̆ında Çorum'da ikamet 
ettiği anlaşılan Derviş Hıdır'ın Nakşi Halidî veya Rifâî tarikatlarından birine bağlı olması kuvvetle muhtemeldir.

Diğer taraftan köyün gerek 1576-77 tarihindeki kayıtlarda En'am Çelebi Zaviyesi'nin vakfı olarak görülmesi gerekse köy ve civarında başkaca bir tekke ve zaviyenin bulunduğuna dair elimizde tarihi bir verinin bulunmaması, Şeyh Hamza tekkesinin inşasına kadar bölgede benzer kamusal hizmet veren bir müessesenin bulunmadığını göstermektedir (Defter-i Mufassal-ı Liva-i Çorum, 2014, s.123). Burada Şeyh Hamza'nın mezarından başka Dobacık Dede ve Dikmen Dede adlarıyla anılan zamanında köyde ve belki de bu bölgede etkin olmuş dinî ve manevi hüviyete sahip zatlara ait mezarlar da vardır. Ancak bu şahısların ne zaman yaşadıkları, Şeyh Hamza ya da Derviş Hıdır ve tekkesiyle bir ilişkilerinin bulunup bulunmadığı kesin olarak bilinmemektedir.

\section{5. ŞEYH HAMZA TEKKESI'NIN EKONOMIK YAPISI}

Tekke ve zaviyeler Osmanlı devletinde sosyal ve içtimai hayatın değişik alanlarında çok önemli görev ve sorumluluklar üstlenmekteydi. Bu çok yönlü müesseselerin daha kuruluşundan itibaren hem devamlılıklarını sağlayabilmelerine hem de resmen tanınarak sisteme dâhil edilmelerine olanak sağlayan temel husus ise ya bir vakfa veyahut da her hangi bir yerin vergi gelirlerinden belli miktarda bir ödeneğin buralara tahsis edilmesine bağlıydı. Nitekim imparatorluğun ilk zamanlarında söz konusu vakıflara ve ihsanlara kavuşmak dönemin siyasi, sosyal ve içtima şartlarında daha kolaydı (Ocak, 1978, s. 256-259). Diğer taraftan her tekkenin popüleritesine göre muhipleri, toplum içerisine dağılan sosyal ağları vardı. Tekke kolektif hayat sürme üzerine inşa edilen bir örgütlü yapıya sahip olup söz konusu sosyal ağlardan gelen nezirler, adaklar, kurbanlar ve bağışlar gündelik yaşam için önemli bir gelir kaynağı sağlamaktaydı (Ay, 2012, s.103). Ancak bunlar hayır hasenat olup düzenli gelir niteliği taşımadığından yine düzenli giderleri bulunan tekkenin işleyişini sürekli kılmaya yetmemekte, dolayısıyla vakıf gelirleri veya tahsisatlar bir kez daha çok önemli bir hal almaktaydı (HSDSABZ. 8/50/1-2, 20 Safer 1275/ 29 Eylül 1858). $\mathrm{Bu}$ durum gerek hizmetlerin sürdürülebilmesi gerekse burada kurulmuş bulunan müesses nizamı sevk ve idare eden şeyh ile dervişlerin geçimlerinin sağlanması başka bir deyişle tekkenin güçlü ve sağlıklı bir sosyo-ekonomik yapıya sahip olması bakımından çok önemli bir husustu.

Nitekim Şeyh Hamza türbe ve tekkesinin daha kuruluşundan itibaren ekonomik istikrar meselesine dayanan sosyo-ekonomik sorunlarla karşı karşıya kaldığı anlaşılmaktadır. Hicri 12 Rebîülevvel 1204 (M. 30 Kasım 1789) tarihli bir belgede Şeyh Hamza'nın mezarı üzerine inşa olunan tekkeden zeytinyağı ve balmumu bedeli tayininin yapılmasının istendiği böylece daha bu tarihten itibaren tekkenin bu konuda bir sıkıntı içerisine girdiği anlaşılmaktadır (C. EV. 21/1003). Yaklaşık 25 yıl sonrasına tekabül eden bir hattı hümayundan hem bu talebin tam olarak karşılanamadığı hem de tekkenin diğer gündelik ihtiyaçları için kalıcı bir çözüm beklentisinin devam ettiği anlaşılmaktadır. Söz konusu belgede Derviş Hıdır'ın ahalinin sevabına yaptığı yardımlarla Şeyh Hamza'nın mezarını tanzim ile üzerine bir türbe ve tekke inşa eylemiş olmasından bahsedildikten sonra adeta asıl meselenin bundan sonra başladığ ifade edilmiştir. Hicri 29.12.1231 (M. 20 Kasım 1816) tarihli bu kayda göre türbede yakılmak üzere "ikad-ı kanadil ve şem' (yakacak kandil ve mum)" ile "tekke-i mezbûreden mürur (geçip giden) ve ubud eden (kalan) fukara ve dervişâna it'am-ı ta'am içün bir nesnesi” olmadığından bahisle münasip bir mahalden yeterli olacak kadar "inayet ve ihsan buyrulmasını" Çorum ahalisinin rica ve niyaz eylediği şehrin naibi tarafindan arz edilmiştir. Buradan Şeyh Hamza tekkesinin benzerleri gibi bir dervişan topluluğuyla âyende ve revendeye yani tekke güzergâhından gelip geçen yolcular ile o mahaldeki fakir fukaraya hizmet ettiğinin vurgulanması aslında diğer tekkelere tanınan bir takım ekonomik hakların talebine yol açan yükümlülüklerin yerine getirildiğini ortaya koymak çabasını açıkça göstermektedir. Zira erken dönemlerde ilk örneklerinden beri bir tekke ve zaviyenin gelirlerinin 
dervişler, miskinler, garipler, fakirler ile âyende ve revendenin hizmeti için harcanması gerektiği vakfiye şartnamelerinde açıkça ifade edile gelmiştir ki Şeyh Hamza tekkesi için talep edilen inayet ve ihsan da bundan başkaca bir şey değildir (İnalcık, 1999, s.190). Nitekim merkezi idare, tekke çevresinden gelen ve Çorum ahalisi üzerinden güçlendirilerek gönderilen taleplere kayıtsız kalmamış ve Sultanın onayı ile birlikte durumun defterdar efendiye havale olunacağ kaydedilmiştir (HAT. 543/26857).

Yaşanan sorunların üç yıl sonrasında da devam ettiğini gösteren kayıtlar bir şekilde kurulan tekke, türbe vb. yapıların öyle hemen kolaylıkla vakıf ve tahsisat gibi düzenli gelirlere sahip olamadıklarını bunun bazen çok uzun boylu mücadeleler sonucu ancak elde edilebildiğini göstermektedir. Diğer taraftan bu durum devletin bu dönemlerde içinde bulunduğu zorlu siyasi, askeri ve ekonomik şartlarla da ilintili olmalıdır. Vesikalara yansıdığ1 şekliyle "merkad-ı şerîfini inşa ve üzerine tekke bina olunmuş ise de türbe-i şerîfde ikad olunacak (yakılacak) kanâdil içün revgan-ı zeyt (zeytinyağı) ile fürûzan (parlayıcı) olacak şem'-i revgan (mum yağı)" kifayet edecek kadar tedariki için ahaliden gelen taleplerle birlikte Çorum Naibi Mevlana Es-Seyd Ali Zeyd Efendi'nin durumu arz ettiği görülmektedir (C. EV. 280/14279/3, 20 Rebîülevvel 1234/M.18 Ocak 1819; C. EV. 280/14279/2, 15 Muharrem 1235/M. 3 Kasim 1819).

Aynı tarihlerde yapıldığ anlaşılan tahkikata göre Şeyh Hamza türbesinin ve zaviyesinin talebinin kandil ve şem'-i revgan (mum yağı) ile sınırlandırılmış olduğu, zaviyenin de hali hazırda şeyhlik beratının bulunmadığı belirtilerek "berât-ı alişân" ile "zaviye-i merkûmun şeyhliği tahsis" edildiği kaydedilmiştir (C. EV. 512/25898/1). Giderek resmen idari ve iktisadi örgütlenmesini tamamladığı görülen türbe ve tekke için Hatt-1 Hümayun gereğince günlük 60 akçe tayin olunmak üzere "senevîsi (seneliği) hesab etdirildikde yüz yetmiş yedi guruşa baliğ olmağla" Şeyh Hamza'nın "merkad-ı şerifinde” yakılacak kandiller için zeytinyağı 20 Rebi-ül-evvel 1234 (M.18 Ocak 1819) tarihinden itibaren Sivas sancağında bulunan Gürcü Köyü mukataası malından alınmak üzere tahsis edilmiştir (C. EV. 280/14279/3; C. EV. 280/14279/2). Nitekim Derviş Hıdır, tahsis edilen bu bedelin 1235 senesine ait bir yıllığını “cem'an yüz yetmiş yedi guruş" olarak mukataa idarecilerinden Ali Ağa'dan teslim almıştır (C. EV. 280/14279/4, 17 Zilhicce 1235/M. 25 Eylü1 1820). Yine benzer şekilde H. 9 Şevval 1255 (M. 16 Aralık 1839) tarihinde de kandiller için bir senelik yağ tahsisatının tamamının tahsil edildiği görülmektedir (C.EV, 399/20213).

Şeyh Hamza tekke ve türbesine ayrılan tahsisatın az olduğu, bir vakfının bulunmadığı (Ilıca, 2001, s.193) tekkenin bir nevi türbeden daha geri planda bırakılarak göz ardı edildiği ve ayrılan tahsisatın belli kalemlerle sinırlandırıldığı görülmektedir. Bu durumun yeni kurulan tekkenin sosyal ağlarının darlığı, çevredeki güç ve nüfuzunun azlığı, küçük, sapa ve dağlık bir arazide kurulan köyün bölgedeki kifayetsiz konumuyla ilgili olduğu söylenebilir. Yine böylesi bir durumla karşılaşılmasında Osmanlı Devleti’nin 18. yüzyılın ikinci yarısından sonra giderek seferlerde özellikle Çarlık Rusya'sına karşı aldığı ağır yenilgilerin, toprak kayıplarının ve buna bağlı olarak yaşanmaya başlanan büyük sosyo-ekonomik sorunların etkileri de göz ardı edilmemelidir (Uzunçarş1l1, 1988, s.465-497). Nihayet oldukça geç bir dönemde de olsa Şeyh Hamza türbesi için (2 Mart 1907) bir vakıf kurulduğu türbenin giderleriyle birlikte imaret hizmetlerinin de yine bu vakıftan karşılandığı kaydedilmiştir (Erkoç, 2015, s.326).

\section{TOPLUM MUHAYYILLESINDE YAŞAYAN ŞEYH HAMZA}

Şeyh Hamza köyünün fiziki, demografik ve sosyo-kültürel yapısını yerinde görmek amacıyla saha çalışması yapılmıştır. Asırlar boyunca Türk İslam medeniyeti içerisinde çok mühim bir yer tutmuş olan şeyhler ve dervişler ile onlardan kalan türbeler, tekke ve zaviyeler ile bunların etrafinda oluşan, kulaktan kulağa aktarılmak suretiyle günümüze kadar ulaşan bir takım menkıbeler 
sosyal tarih ve sosyoloji araştırmaları bakımından büyük önem arz etmektedir. Zira özellikle sözlü kaynaklar hem geçmiş zamanların inançlarına, değerler silsilesine işaret etmekte bu tarihi şahsiyetlerin günümüz toplumları üzerindeki etkilerini ortaya koymakta hem de zamanla anlam ve mahiyetinde farklılıklar ortaya çıktığı görülen bu öyküler sayesinde tarikatların tabii gelişim süreçlerine açıklık getirmektedir (Ocak, 1992, s.97). Hattı zatında evliya menkıbelerinin kahramanları gerçek, zamanı ve mekânı bellidir. Takdis edilen şahıslar etrafında cereyan eden ve dönemin topluluklarınca gerçekliğine güçlü bir şekilde inanılan hadiselerdir (Ocak, 1992, s.33). Nitekim Köprülü, menkıbelerin olağanüstü hikâye örgüsü altındaki gerçekliği "Halk muhayyilesinin yarattığı menkıbeler daima hakikat cüzünü de içine alı»” (2013, s.85) ifadesiyle ortaya koymuştur. Hasluck, Türk zümrelerinin dini etnografyası hakkında maddeler toplamak amacıyla oluşturdukları hususi merkezin yayın sahasındaki faaliyetlerini sınıflandırırken Türklerin dini tarihini aydınlatacağını düşündükleri vesikalar ve evliya menkıbeleri için ayrıca bir bölüm oluşturduklarını kaydetmiştir (2012, s.19). Barkan ise olaya başka bir açıdan yaklaşarak mistik bir yapıya haiz olan tarikatların zamanlarında ne büyük bir kuvveti temsil ettiğine, aralarına aldığı halk kitlesini muayyen sosyal nizamlar için nasıl harekete geçirdiğine işaret ederek adeta söz konusu yapıların ve şahısların halkın nazarında menkıbevi, yüksek konuma nasıl ulaştıklarına açıklık getirmiştir (1942, s. 284-285). Yine burada tarihi ve sosyolojik olarak dikkat çekilmesi gereken bir husus da genellikle kırsal alanda bulunan türbe, tekke ve zaviyeler etrafında bu tür menkıbelerin yoğunluk kazanması ya da köylülerin hala toplumsal hafızalarında bu tür menkıbeleri tutuyor olmalarıdır. Zira bu durum sosyolojik bakımdan bir nevi geleneksel formlara daha bağlı ve bağımlı olan kırsal toplulukların sanayi ve kent toplumundan ayrılan yönüne de işaret etmektedir (Weber, 2012, s.186). ${ }^{8}$

Nitekim Şeyh Hamza türbesi etrafında da birtakım menkıbelerin anlatıla geldiği görülmektedir. Mesela türbe çevresinde bulunan çam ağaçlarından bir parça götürenin evinde yangın çıkacağına inanıldığından buradaki ağaçlara dokunulamadığı kaydedilmiştir (Erkoç, 2015, s. 326). Diğer bir menkıbede türbenin etrafında nahoş bir şekilde içki içerek eğlenenlerin başına türlü türlü belalar geldiği belirtilirken bir diğerinde ise çıkan bir yangın hadisesinde etrafındaki otlar yandığı halde Şeyh Hamza türbesine ateş sıçramamıştır (Erkoç, 2015, s. 326).

Yukarıda izah edildiği üzere kayıtlardaki faaliyet alanlarından tekke, türbe ve imaretten oluştuğu ve klasik Osmanlı tekke ve zaviyelerine ait özelliklere haiz bulunduğu anlaşılan Şeyh Hamza külliyesinde önce tekke ardından da imaret giderek devre dışı kalmıştır. Tekke, zaviye ve türbelerin kapatılmasıyla da zamanla söz konusu bu yapılar tamamen kaybolmuş olmalıdır. Nitekim yerinde yapılan araştırmada da görüldüğü üzere bugün Şeyh Hamza türbe, tekke ve imaretinden geriye tarihi bir yapı kalmamıştır. Tarihi ahşap türbe (Ali İzzet Efendi, 1997, s. 106) muhtemelen tadilatlara uğramış son hali 2012 yılında tamamen yıkılarak yerine günümüz koşullarında uzunca bir yapı inşa edilmiştir (EK 6). Hemen girişi mescit olan bu mekânın içinden açılan bir kapıyla da Şeyh Hamza türbesine geçilmektedir. Türbe bugün hala ziyaret edilmeye halktan teveccüh görmeye devam etmektedir. Hatta tekke ve zaviyelerde bulunan diğer türbe örneklerinde olduğu gibi buranın da zamanında belli hastalıklardan kurtulmak amacıyla ziyaret edildiği düşünülebilir. ${ }^{9}$ Tekkenin yok olmasıly birlikte tarihi imaret özellikleri tam olarak yaşatılamasa da türbenin üst tarafında yemek pişirme ve ikram etme ihtiyaçlarına da cevap verebilecek tarzda mütevazı bir yapı daha inşa edilmiştir (EK 7). Şeyh Hamza türbesi ve etrafı aynı zamanda köyün mezarlığı olarak da kullanılmaktadır. Bugün türbe etrafında bulunan ve çok yaşlı oldukları anlaşılan ağaçlardan türbe ve tekkenin kurulduğu alanın çok eski bir yerleşim yeri olduğu hemen anlaşılmaktadır. 
Şeyh Hamza'nın kabrinden başka köyün üst tarafında dağlık, tepelik bir yerde Dobacık Dede ile hemen yakınlarında Dikmen Dede'nin mezarları bulunmaktadır. Bundan başka Şeyh Hamza köyü yolu üzerinde Helvacı Baba'nın kabri yer almaktadır (Ali İzzet Efendi 1997, s. 88). Söz konusu bu tarihi şahsiyetlerin Şeyh Hamza tekkesinde seyr u sülûk eğitimi almış dervişler, halifeler veya onun akrabaları olma ihtimalleri de vardır.

Bütün bu bilgilerden anlaşılacağı üzere Şeyh Hamza külliyesi tekke ve imaretin ortadan kalkmasıyla birlikte sosyal hayat üzerindeki birçok işlevini kaybetmekle birlikte türbesi bugün hala halkın muhayyilesinde yaşamaya, sosyo-psikolojik ve kültürel olarak gündelik hayata etki etmeye devam etmektedir.

\section{SONUÇ}

Şeyh Hamza medfun bulunduğu köy ve civarında yaşadığı dönemde etkin olmuş, öldükten sonra da zamanla mezarının yeri kaybolmasına ve unutulmasına rağmen bölge halkının inanç ve zihin dünyasında, manevi yaşantısında tesirini sürdürmeye devam etmiştir. $\mathrm{Bu}$ durum onun karizmatik bir dinî lider olarak bölge halkının sosyal ve içtimai yaşantısıyla özdeşleşmiş tarihi bir kimliğe sahip bulunduğunu göstermektedir.

Şeyh Hamza türbesinin bulunarak üzerine türbe ve yanına bir tekke inşa edilmesi meselesi gerek Osmanlı toplumunun inançlarına, dinî ve manevi yaşantısına dair önemli veriler sunması gerekse bütün bu değerler silsilesi üzerinde tasavvufî 1stılahların etkinlik derecesini göstermesi bakımından dolayısıyla sosyal tarih araştırmaları açısından çok önemlidir. Zira rüya gibi tasavvufí bir 1stılahla yola çıkılmış, Derviş Hıdır'ın rüyası hem toplumu hem de Çorum naibi başta olmak üzere kamusal alanı harekete geçirmek için yeterli olmuştur. Şeyh Hamza'nın türbesi ve tekkenin inşasında halkın gönüllü ve yardımsever tavrı hafızalarında pek mübarek ve saygın bir yer tutan ve veli olduğundan şüphe duymadıkları anlaşılan bu zatın, üzerlerindeki dinî ve manevi nüfuzunu açıkça göstermektedir.

Şeyh Hamza tekkesi en erken 18. yüzyılın ortalarında tarih sahnesine çıkmıştır. Tekke ve zaviyelerin kurulma ve yaygınlaşma süreci bakımından geç bir dönemde kurulduğu anlaşılan tekke, zamanının karakteristik bir örneğini sunması nedeniyle de araştırmacılar açısından büyük bir öneme sahiptir. Zira türbe ve tekkenin resmi olarak sisteme adaptasyonu uzun sürmüş, bu sağlandığında da tekke, maalesef ilk dönemlerde daha kolay elde edilen zengin vakıflara ve tahsisata kavuşamamıştır. Şüphesiz bu durumda zamanla tekke ve zaviyelerin fütuhat, iskân ve yeni fethedilen yerlerdeki toplulukları irşat dönemlerinde yürüttükleri söz konusu fonksiyonları önemli ölçüde kaybetmelerinin etkisi büyük olmuştur. Hatta ufak misafirhaneler halinde teşekkül ettirilen bazı zaviyeler başlangıçtaki tasavvufi-dolayısıyla dini ve manevi- hüviyete sahip formlarını zamanla kaybetmiş ve sadece birer misafirhane, imarete dönüşmüştür(Ocak, 1978, s. 250). Söz konusu durumun oluşmasında bunlardan başka imparatorluk tarihi boyunca ülke sathına yayılan tekke ve zaviyelere ayrılan vakıf arazi ve tahsisatın büyük bir yekûna ulaşmasının ve yine bu dönemde devletin içinde bulunduğu zor siyasi, askeri ve ekonomik şartların da etkisi olmuştur.

Bütün bu olumsuzluklara rağmen Derviş Hıdır ve bölge halkının gayretiyle inşa edilen Şeyh Hamza türbesi ve tekkesinin kamusal alana intibakında tekkenin, Çorum-Laçin-Osmancık güzergahında önemli bir geçit yolu üzerinde bulunmasının ve civarda bu türden hizmet verecek başkaca bir müessesenin bulunmamasının etkisi büyük olmuştur. Nitekim Şeyh Hamza'nın türbe, tekke ve imaretinden oluşan külliyesi buradan gelip geçen yolculara, fakir fukaraya, türbe ziyaretine gelenlere ve dervişâna bir tekkeden beklenen bütün konaklama ve imaret hizmetlerini sunmuştur. 
Asıl adı Hacı Bey Ağacı olan köyün isminin Şeyh Hamza'nın mezarının bulunması, türbe ve tekkenin inşası ardından 19. yüzyıl ortalarından itibaren değişerek Şeyh Hamza'ya dönüştüğü görülmektedir. Bu durum araştırmacıların köyler, beldeler ve isimleri üzerinde çalışırken her köyün ismini taşıdıkları tarihi, manevi şahsiyetler tarafından kurulduğu şeklinde sıklıkla başvurulan genellemelerde bulunurken daha dikkatli olmaları gerektiğini açıkça ortaya koymuştur.

Tekke ve zaviyelerin zamanla-özellikle 19. yüzyılda- birçok fonksiyonunu kaybetmesiyle buraların bir köy, belde camiine dönüşme süreci Şeyh Hamza'da da gerçekleşmiş tekke ve imaret tarihe karışmış, türbe ve yanına inşa edilen mescit faaliyetini sürdürmeye devam etmiştir. Şeyh Hamza türbesi, bugün hala ziyaret edilen, sosyal ve kültürel yaşamın birçok alanında etkili olmaya devam eden canlı dinamik bir yapıya haizdir.

\section{Açıklamalar}

1) Eyice'ye göre Elvan Çelebi köyünün bulunduğu yerde bir yerleşim olmayıp burada bulunan ziyaretgâh ve manastır mevkiinin Elvan Çelebi zaviyesine dönüştürülmesi ardından Elvan Çelebi köyü haline gelmesi mümkün ve mantıkîdir. Dolayısıyla bölgedeki Türkmen yerleşiminde Elvan Çelebi ve zaviyesi önemli bir rol oynamıştır (Eyice, 1969, ss. 233-234, ss. 240-241; Erünsal-Ocak 1995, s. XXVIII); Veysel Karâni evlâdından Şeyh Zeynüddin'in halifesi ve akrabası olduğu anlaşılan Piri Baba tarafından kurulan tekke ise Çorum'un Samsun istikametinde hemen şehrin çeperlerinde kurulmuştur (C. EV. Nr. 512/25886, H. 29 Cemaziyelevvel 1197/M. 2 May1s 1783; C. EV. Nr. 141/7045, H. 1 Rebiülevvel 1248/M. 28 Ağustos 1832). Seyyid Murat Zaviyesi ise Çorum-İskilip-Çankırı yol güzergâhında önemli bir geçit bölgesinde kurulmuş hem Türkmen aşiretlerinin iskânında hem de daha sonraları bir derbentle de korunmak durumunda kalındığı anlaşılan bölgenin güvenliğinin sağlanmasında önemli bir işlev görmüştür (DH. MKT. Nr. 1618/58, 21 Şaban 1306/22 Nisan 1889).

2) Yaşanan bu tarihi süreç özellikle 16. yüzyıldan başlayarak tarikatların gerek idari, sosyal ve ekonomik gerekse taşıdıkları inanç değerleri bakımından özerk, özgür ve özgün karakterlerini hızla devlete eklemlenmek suretiyle büyük ölçüde yitirdikleri de bir dönemdir (Işık 2015, ss. 68$71)$.

3) Tarikatların, gazi dervişlerin Osmanlı kuruluş evresinde fütuhata ve iskâna olan doğrudan katılımları devletin güçlü profesyonel bir ordu eşliğinde bütün bir müesses nizamıyla ortaya çıkmaya başladığı Osmanlı klasik çağından itibaren sona ermiştir. Bu durum giderek yerini Ordu Şeyhliği denilen dönemin meşhur tarikat şeyhlerinden birisi ve birkaç dervişinin seferlere katılımıyla orduyu manevi olarak motive etmesi beklenen bir forma dönüşmüştür (Ekin, 2008, s. 167 -178). Lûtfî Efendi'nin tabiriyle ordu şeyhleri “...ordu-yı hümâyûnlarda tavâif-i askerîyyeyi emr-i gazâ ve cihâda igrâ ve asâkir-i İslamiyyenin muzafferiyyetine duâ içün..." vazifelendirilmişlerdir (Lûtfî Efendi, 1999, s. 189).

4) Hicri 3 Rebîülâhir 1308/M. 16 Kasım 1896 tarihli bir vesikaya göre Şeyh Hamza mezrası hasılatından söz konusu camii görevlileri ve burada tahsil gören talebelere varidat ayrıldığ görülmektedir (Çorumlu Dergisi, 1944, ss. 398-399). 
5) 1576-1677 yıllarında Çorum'da kullanılan erkek adlarına dair tafsilatlı bir çalışma için bk. (Kurt, 1991, ss. 57-102).

6) Bir insan ömrü ve bilinen önemli tarihlerden yararlanılarak Şeyh Hamza'nın mezarının ne zaman keşfedildiği yaklaşık olarak hesaplanabilir. Derviş Hıdır'ın mezarın rüya yoluyla keşfedilmesini sağlaması ve buna etrafındakileri inandırmış olmasına bakılırsa o dönemde (1789 öncesinde) manevi bir olgunluğa sahip, en azından 30-40 arasında, orta yaşlarda bir derviş olduğu düşünülebilir. Buna göre o, türbedarlık ve tekke meşihatını resmen talep ettiği 1819 tarihinde yaklaşık 60-70 yaş aralığında olmalıdır. Bu durumda 1819'dan ortalama 30-40 y11 geriye gidildiğinde yine tahminen bu keşfin 1780'li yıllarda veya biraz öncesinde vuku bulduğu kabul edilebilir.

7) Tarikatların formasyonu her yerde görünen bir takım temel niyetler ve kavramlar dizisini kabullendirmede oldukça başarılıdır ki rüya da şüphesiz bunlardan birisi olmalıdır (Mensching, 2012, s. 215). Tasavvufta bilgi kaynağ1 olarak kabul edilen rüyanın, Kuşeyrî̀ye göre kalbe gelen hatır ve muhayyile ile tasavvur edilen bir hal olarak tarif edildiği, yine tasavvufî gelenekte rüya tabirinin ise misal âlemi denilen nurâni âleme ait ilimlerden sayıldığı kaydedilmiştir (1993, Kayacı 2018'den). Nitekim Mutasavviflar önemli konularda rüya yoluyla elde ettikleri bilgiler doğrultusunda hareket ettiklerini ileri sürmüşlerdir(Çelebi, 2008, s. 307). Şeyh Bedreddin'e göre temiz rüya Hakk’ın nurlarından bir nurdur, gören onunla 1şıklanır ki onlardan, onları yormaktan gaflet etmemek gerekir (Şeyh Bedreddin, 2008, s. 152). Molla Cami'ye göre ise abdestle, zikirle uykuya dalan bir kimsenin ruhunu arşın altına götürüler orada Yüce Allah'ın ibadeti ile meşgul olurlar. Bu halde gördükleri rüyalar ise doğru olur (Molla Cami, 2011, s. 84). Nitekim Kürtler içerisinde doğup büyüyen Seyyid Ebu’l Vefâ rüyasında Hz. Peygamber’i görmüş, Hz. Peygamber onun ağzına "mübarek ağzının yarından koymuş" sabah olduğunda ileri seviyede Arapça konuşabilir bilgiye ulaşmış halde uyanmıştır (Seyyid Ebu'l Vefa, 2006, ss. 41-42). Bütün bunlardan başka seyr u sülük eğitimi sürecinde rüya aynı zamanda önemli bir rehberdir. Şeyh müridinin rüyalarını yorumlar, düşüncelerini okur ve böylece bilinçli ve bilinç dışı hayatına dair hareketlerini izler (Schimmel, 2012, s.120).

8) Hadiseye sosyolojik açıdan yaklaşan Mensching'e göre bu tür menkıbeler aslında toplumun her hangi bir kesiminden daha fazla tabiatın yüksek kudreti ile mücadele eden köylülerin müşküllerini ve korkularını dinî, manevi, mistik bir kurtarıcı etrafında halletmeye dönük sosyopsikolojik halleriyle ilgilidir. Söz konusu sosyal çevrelerin sorunlar karşısında çözüm getirici maddi unsurlara sahip bulunmayışı onları bir kurtarıcıya, Tanrıyla arasına girerek bütün meseleleri halledebilecek, ihtiyaçları karş1layabilecek mahiyette dini, manevi yetilere sahip bir aracıya yöneltmiştir (2012, ss. 273,152).

9) Gerek meşâyihin, gerekse türbelerinin bir takım hastalıkların tedavisinde dini ve manevi bir güce sahip oldukları yönünde geriye doğru gidildikçe artan güçlü bir inanış vardı. Mesela Mevlevi Şeyhi Bostan Çelebi'nin dua ve himmetiyle İsmail Rusuhî Ankaravî’nin gözleri açılmıştır (İsmail Rusuhî Ankaravî 2008, s. 20). Sultan Süleyman'in oğullarından birisinin hasekisine musallat olan hastalığı Kademli Baba iyileştirmiştir (Demir Baba Velâyetnâmesi 2011, ss. 47-48). 
Menkıbelerden başka bu hususta tarihi vesikalarda da bilgiler bulmak mümkündür. Mesela Musul havalisinde akıl hastalarını tedavi eden Alemdar Şeyh Ahmed Efendi'ye maaş tahsis edilmiştir (İ. DH. Nr.1313/1311, 26 Za 1311/ 31 Mayıs 1894). Erzurum civarında yine akıl hastalarını tedavi eden ve darüşşifa hükmünde olarak nitelenen tekkenin yerinin söz konusu tedaviyi yürüten şeyh ailesine tahsisi söz konusu olmuştur (C. EV. 434/21977, 30 M 1147/ 2 Temmuz 1734). Benzer şekilde meşâyihin hastalıkları tedavisi türbeleri aracılığıyla da devam etmiştir. Mesela Çorum Kale Mahallesi Veli Paşa Camii yakınlarında bulunan Uyuşuk Dede'nin kollarında bacaklarında uyuşukluk hastalığı olanlarca ziyaret edilmesi halinde Allah'in izniyle hastalıktan kurtulacağına inanılmaktadır (Ali İzzet Efendi 1997, s. 68). Yine Hasan Balım Sultan türbesine vücudunun her hangi bir yerinde ağrı, sızı çeken hastaların geldikleri ve türbede hali hazırda bulunmaya devam eden uzun saplı tokmaklı bir çubuğu sürmek suretiyle ağrılarından kurtulduklarına inanılmaktadır (Işık, 2018, ss. 315-334).

\section{KAYNAKÇA}

Abdullah Lütfi Efendi (1999). Vak'anüvîs Ahmed Lûtfî Efendi Tarihi. (Çev. Ahmet Hazarfen). C. I, İstanbul: Yapı Kredi Yayınları.

Ali İzzet Efendi (1997). Tezkire-i Makamat, (Haz. Mahmut Selim Gürsel). Çorum: İstikamet Ofset.

Âşık Paşazade (2003). Osmanoğulları'nın Tarih, (Hazırlayanlar, Kemal Yavuz- M. A. Yekta Saraç), İstanbul: K Kitaplığı Yayınları.

Ay, R. (2012). Anadolu'da Derviş ve Toplum 13-15. Yüzyıllar. İstanbul: Kitap Yayınevi.

Bademci, A. (2019). Şamanizmden Kızılbaşlığa Şiîliğin Türmen Yüzü. Konya: Çizgi Kitapevi.

Bakırer, Ö. (2015). Bizans, Danişmend, Selçuklu ve Beylikler Dönemlerinde Çorum (Haz. Mustafa Ercan, İrfan Yiğit). Çorum Tarihi, 5. Hitit Festival Komitesi, Çorum Belediyesi Kültür Yayını, 53-78.

Barkan, Ö.L. (1942). İstila Devirlerinin Kolonizatör Türk Dervişleri Ve Zaviyeler. Vakıflar Dergisi, (II) 279-304.

Bulduk, Ü.(1992). Çorum Sancağının Osmanlı İdari Teşkilatındaki Yeri-1. Osmanlı Tarihi Araştırma ve Uygulama Merkezi Dergisi, (3) 129-167.

Cevdet Tasnifi (C. EV), 399/20213.

Cevdet Tasnifi (C. EV), 21/1003.

Cevdet Tasnifi (C. EV), 280/14279/1,2,3,4.

Cevdet Tasnifi (C. EV), 434/21977.

Cevdet Tasnifi (C. EV), 492/24865.

Cevdet Tasnifi (C. EV), 512/25898/1,2.

Cevdet Tasnifi (C. EV), Nr. 141/7045.

Cevdet Tasnifi (C. EV), Nr. 512/25886. 
Çanak(Erten), A. (2013). Abdal Ata Zaviyesi. Yüksek Lisans Tezi, Sivas: Cumhuriyet Üniversitesi.

Çanlı, M. (2013). Ankara, Kastamonu, Sivas Osmanlı Vilayet Salnamelerinde Çorum (1869-1908). Çorum Belediyesi Kültür Yayını.

Çelebi, İ. (2008). Rüya. Türkiye Diyanet Vakfı İslâm Ansiklopedisi. C. 35, 306-309.

Çorum Şeriye Sicilleri (2009). (Haz. Çorum Belediyesi Kent Arşivi), Çorum Belediyesi Kültür Yayınlar1.

Dahiliye Mektubi Kalemi (DH. MKT.)

Demir Baba Velâyetnâmesi (2011). Haz. Filiz Kılıç - Tuncay Bülbül, Ankara: Grafiker Yayınları.

DH. MKT. Nr. 1618/58.

Ekin, Ü. (2008). Osmanlı Ordusunda Moral Yükseltici Bir Kurum Olarak Ordu Şeyhliği. Sakarya Üniversitesi Fen Edebiyat Fakültesi Dergisi, 10/1, 167-178.

Erginli, Zafer (2002). “Osmanlı Devleti’nin Kuruluşunda Türk Dervişlerinin İzleri”, Türkler, Ankara: Yeni Türkiye Yayınları, ss.107-115.

Erkoç, E. (2015). Çorum'da Sahabe Ve Evliya Makamları, Çorum Belediyesi Kültür Yayınları.

Erünsal, İ. E. (2003). XV-XVI. Asır Bayrami Melamiliğinin Kaynaklarından Abdurrahman elAskeri'nin Mir'atü'l-Işkı. Anakara: Türk Tarih Kurumu Yayınları.

Erünsal, İ. E. ve Ocak, A.Y. (1995). Elvan Çelebi Menâkıbu'l-Kudsiyye Fî Menâsıbi’l-Ünsiyye-Baba İlyas-ı Horasânî ve Sülalesinin Menkıbevi Tarihi. Ankara: Türk Tarih Kurumu Yayınları.

Eyice, S. (1969). “Çorum'un Mecidözü'nde Âşık Paşa-Oğlu Elvan Çelebi Zâviyesi”, Türkiyat Mecmuası, C. 15, ss. 211-246.

F.W. Hasluck (2012). Bektaşi Tetkikleri (Çev. Ragıp Hulusi-Haz. Mehmet Kanar). Ankara: Milli Eğitim Basımevi.

H.984 (M.1576/1577) Tarihli ve TKG.KK.TTd.54 Numaralı Defter-i Mufassal-ı Liva-i Çorum., (1. Cilt, Tıpkıbasım). T.C. Çevre ve Şehircilik Bakanlığı, Tapu ve Kadastro Genel Müdürlüğü, Arşiv Dairesi Başkanlığı Yayın No: 8, Ankara 2014. (TKGMA TTd 54).

HAT. 543/26857.

Hatt-1 Hümâyûn Tasnifi (HAT)

HSDSABZ.8/50/1-2, 20 Safer 1275/ 29 Eylül 1858).

Ilıca, A. (2001). Çorum Vakıfları, Yüksek Lisans Tezi. Bursa Uludağ Üniversitesi.

Işık, Z. (2018). Hasan Balım Sultan Zaviyesi'nin Sosyo-Ekonomik Ve Kültürel Tarihi. Turkish Studies, (13)3, 315-334.

Iş1k, Z. (2015). Şeyhler ve Şahlar-Osmanlı toplumunda Devlet Tarikat İlişkilerinin Gelişim ve Değişim Süreçleri. Konya: Çizgi Kitap Evi.

İ. DH. Nr.1313/1311. 
İbnülemin Tasnifi (İE.)

İE. EV. Nr. 46/5187.

İnalc1k, H. (1999). Ahilik Toplum Devlet, II. Uluslararası Ahilik Sempozyumu Bildirileri, Ankara: Kültür Bakanlığ Yayınları.

İrade Tasnifi Dâhiliye (İ. DH.)

İsmail Rusuhî Ankaravî (2008). Osmanlı Tasavvuf Düşüncesi (Makâsıd-ı Aliyye Fî Şehri't-Tâiyye) Haz. Mehmet Demirci. İstanbul: Vefa Yayınları.

Karaca, Behset-Karaboğa, Durmuş Volkan, "Osmanlı Medeniyeti, Yerleşmesi ve İskânına Etki Eden En Önemi Kurumlardan Biri Olan Tekke ve Zaviyeler: Hamid Sancağı Örneği”, History Studies, 11/5, Ekim 2019, ss.1585-1606.

Kayacı, M. (2018). Tasavvuf Geleneğinde Rüya-Psikolojik Bir Yaklaşım. Yüksek Lisans Tezi. Çorum: Hitit Üniversitesi.

Korkmaz, Ş. (2003). Çorum'un İdari Sosyal ve Ekonomik Yapısı (Tanzimat-II. Meşrutiyet). Doktora Tezi. Ankara: Gazi Üniversitesi.

Köç, A. (2016). Osmanlı Devleti’nde Devlet-Tekke İlişkisinin Önemli Bir Tanığı: Halveti Şeyhi Sofyalı Bâlî Efendi Ve Vakıfları. Belleten, LXXX, 797-821.

Köprülü, M. F. (2013). Türk Edebiyatında Illk Mutasavvıflar. Ankara: Akçağ Yayınları.

Köseoğlu, N. (2009). “Çorum'da Oğuz Boyları”, (Haz. İrfan Yiğit). Çorumlu Dergisi, C. III, Çorum: Çorum Belediyesi Kültür Yayınları, 1277-1283.

Köseoğlu, N. (2009). “Tarihte Çorum Köyleri, Ayas, Türkler ve Bölgesi,” (Haz. İrfan Yiğit). Çorumlu Dergisi, C. I, Çorum: Çorum Belediyesi Kültür Yayınları, 484-489.

Kurt, Y. (1991). XVI. "Yüzyılda Çorumlu Kazası Kişi Adları", 26-27 Temmuz 1991 Uluslararası 11. Çorum Hitit Festivali, Türk Kültür Tarihi İçerisinde Çorum Sempozyumu Tebliğleri, Kültür Bakanlığı Katkılarıyla, Çorum Belediyesi Yayınları, 57-102.

Kuşeyri, A. (1993). er-Risâletü'l-Kuşeyriyye, Tah. Maruf Zerrik-Abdulhamit Baltact, Beyrut.

Mensching, G. (2012). Din Sosyolojisi (Çev. Mehmet Aydın), İstanbul: Litera-Türk Yayınları.

Molla Camî (2011). Nehafet'ül Üns Hadarât'il Kudüs-Evliya Menkıbeleri (Sadeleştiren Abdülkadir Akçiçek). Huzur Yayınevi.

Ocak, A. Y. (1978). "Zaviyeler" Vakuflar Dergisi, C. XII, ss. 247-270.

Ocak, A. Y. (1992). Kültür Tarihi Kaynağı Olarak Menakıbnameler (Metodolojik Bir Yaklaşım), Ankara: Türk Tarih Kurumu Yayınları.

Öz, M. (1991). 15 ve 16. Yüzyılda Çorum Sancağı Nüfus ve İktisadi Hayat. Uluslararası 11. Çorum Hitit Festivali, Türk Kültür Hayatında Çorum Sempozyum Tebliğleri, Çorum Beldeyiesi Yayınları. 
Özdemir, R. (1994). “Osmanlı Devleti'nin Tarikat, Tekye ve Zaviyelere Karşı Takip Ettiği Siyaset” OTAM (Ankara Üniversitesi Osmanlı Tarihi Araştırma ve Uygulama Merkezi Dergisi), S.5, ss.259-310.

Schimmel, A. (2012). İslam'ın Mistik Boyutları (Çeviren Ergun Kocabıyı)). İstanbul: Kabalc1 Yayınları.

Sivaslı Ali Baba Zaviyesi Vakfı Evrakı (HSDSABZ)

Şahin, H. (2012). "Vefâiyye, Türkiye Diyanet Vakfı İslam Ansiklopedisi, C. 42. 600-603.

Şahin, H.H. (2017). Çorum Nüfus Defterleri 1844. Ankara Okulu Basım Yayın Ltd. Şti.

Şahin, İ. (1993). “Çorum”, Türkiye Diyanet Vakfı İslam Ansiklopedisi, C. 8, 373-376.

Şeyh Bedreddin (2008). Simavna Kadısıoğlu Şeyh Bedreddin ve Menâkıbı, Haz. Abdülbâki Gölpınarlı-İsmet Sungurbey. İstanbul: Milenyum Yayınlar1.

Tacü'l Arifîn Es-Seyyid Ebu'l Vefâ (2006). Tacü’l Arifìn Es-Seyyid Ebu’l Vefâ Menakıbnâmesi (Haz. Dursun Gümüşoğlu) İstanbul: Can Yayınları.

Temettuat Defteri: ML. VRD. TMT.d. Nr. 521/2.

Tonbuş, N.(1940). "Danişmendnâme ve Mirkatü'l-Cihat”, (Haz. İrfan Yiğit), Çorumlu Dergisi, C. II, Çorum: Çorum Belediyesi Kültür Yayınları, 21, 654-658.

Uzunçarşıll, İ. H. (1988). Osmanlı Tarihi, IV/I. Ankara: Türk Tarih Kurumu Yayınları.

Yiğit, İ. (t.y.) Osmancık’ta Kadı Ferahşad'a Ait Vesika (Haz. İrfan Yiğit). Çorumlu Dergisi, C. III, Çorum: Çorum Belediyesi Kültür Yayınları, ss. 398-400.

Weber, M. (2012). Din Sosyolojisi (Çeviri Latif Boyac1). İstanbul: Yarın Yayınlar. 


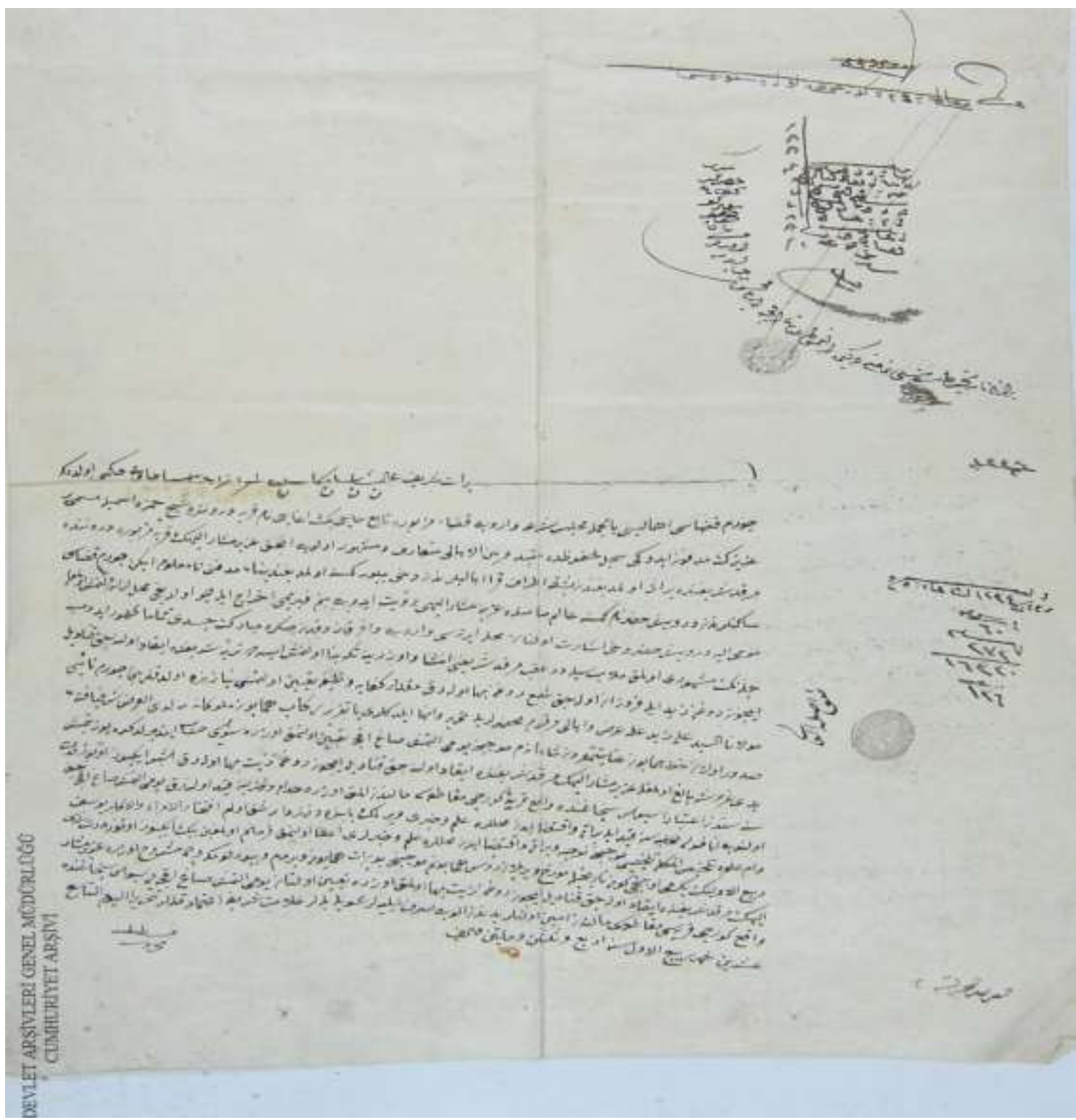

EK-1: Derviş Hıdır'ın rüyasıyla başlayan Şeyh Hamza'nın mezarının bulunması, üzerine türbeyle yanına tekke inşa edilmesi süreci ile devam eden, Çorum naibi ve ahalinin türbe-i şerifte yakılacak kandiller için zeytinyağı, parlatıcı ve şem'-i revgan (mum yağı) talebi hususlarını içeren belge. (C. EV. 280/14279-1, H. 20 Rebiülevvel 1234/M. 17 Ocak 1819). 


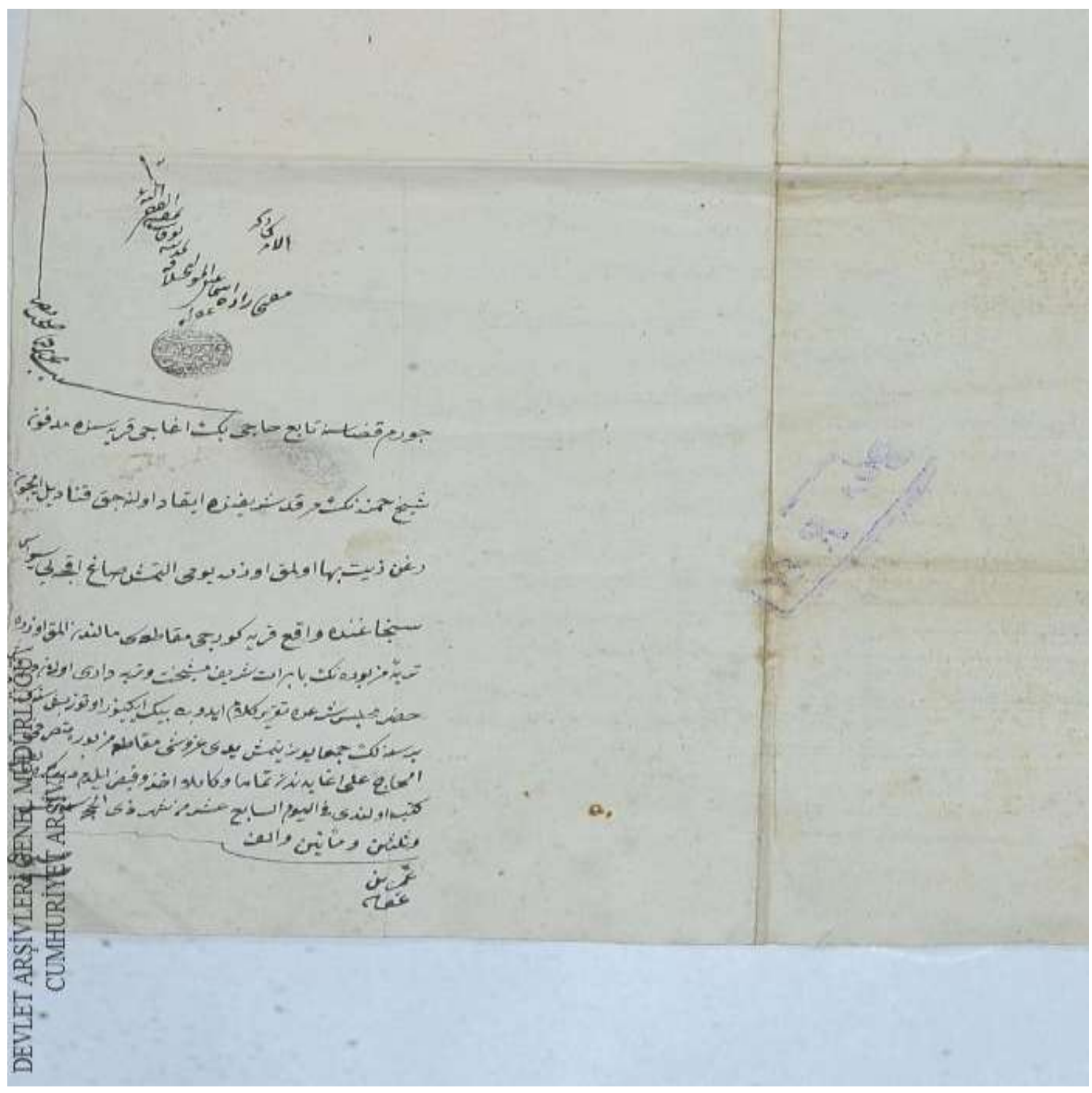

EK-2: Sivas Sancağında bulunan Gürcü Köyü mukataası malından alınmak üzere Şeyh Hamza türbesine tahsis edilen miktarın 1235 senesine ait bir yıllık bedelinin "cem'an yüz yetmiş yedi guruş” olarak Derviş Hıdır tarafından mukataa idarecilerinden teslim alındığını aktaran vesika (C. EV. 280/14279-4, 17 Zilhicce 1235/M. 25 Eylül 1820). 

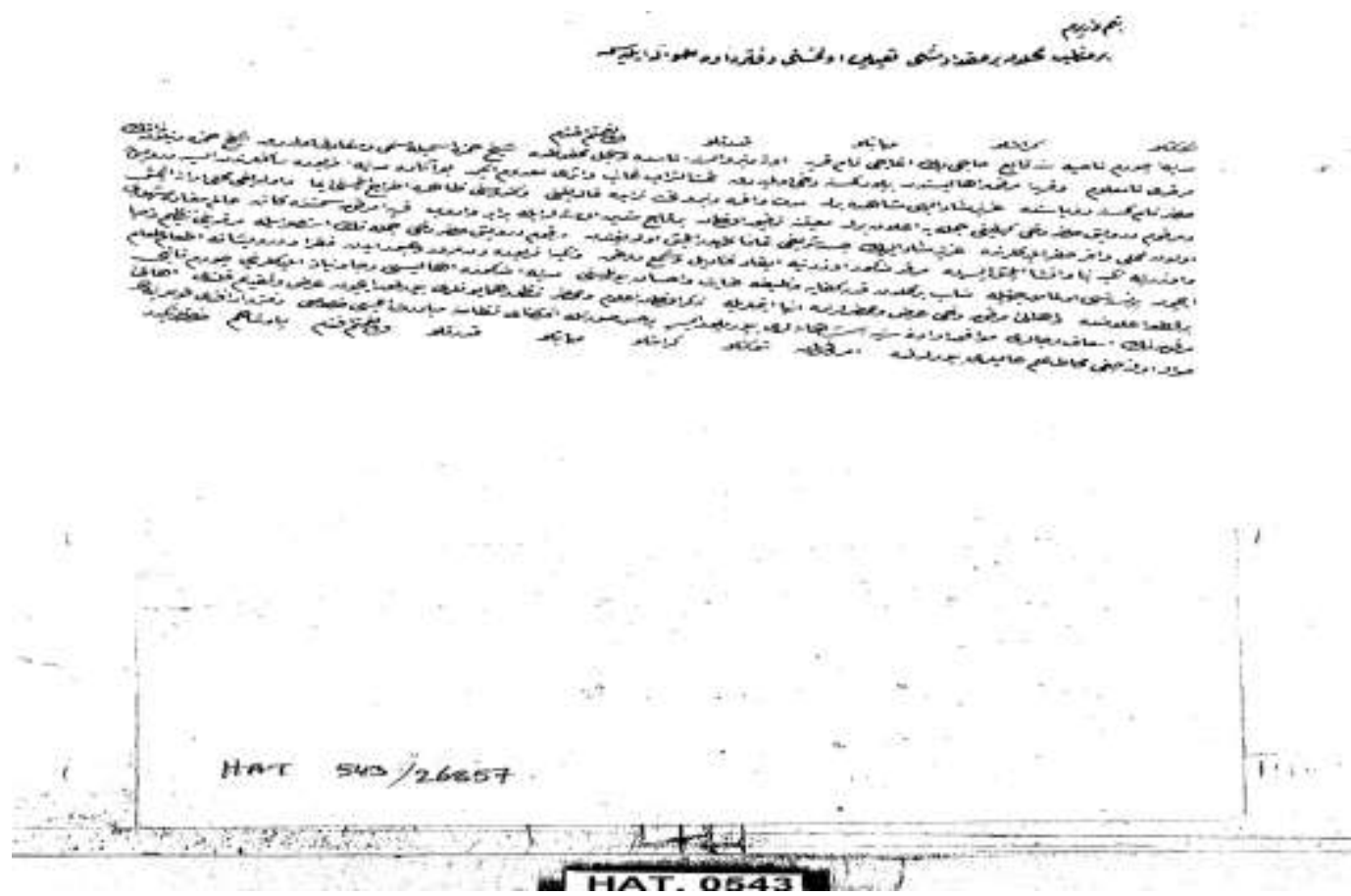

EK-3: Şeyh Hamza türbesinin kandil ve mum ihtiyacı ile tekkeye gelip geçerken uğrayan yolcuların ve burada kalan fukara ve dervişânın taamiyesi için inayet ve ihsan buyrulması talebi hakkında Hatt-1 Hümayun (HAT. 543/26857-1 (H. 29 Zilhicce 1231/M. 20 Kasım 1816). 


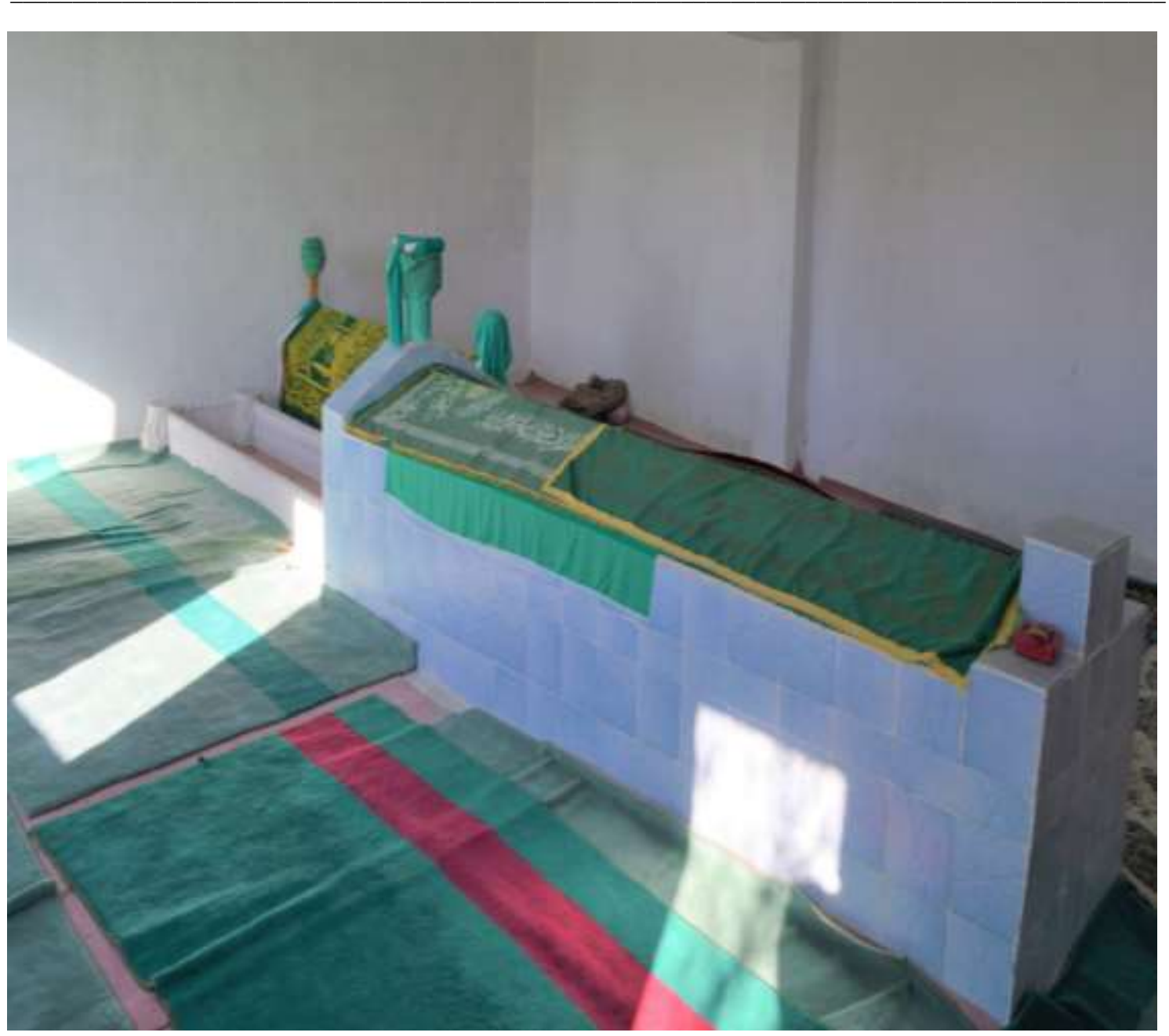

EK-4: Şeyh Hamza'nın kabri(uzunca mermer kaplı olan). 


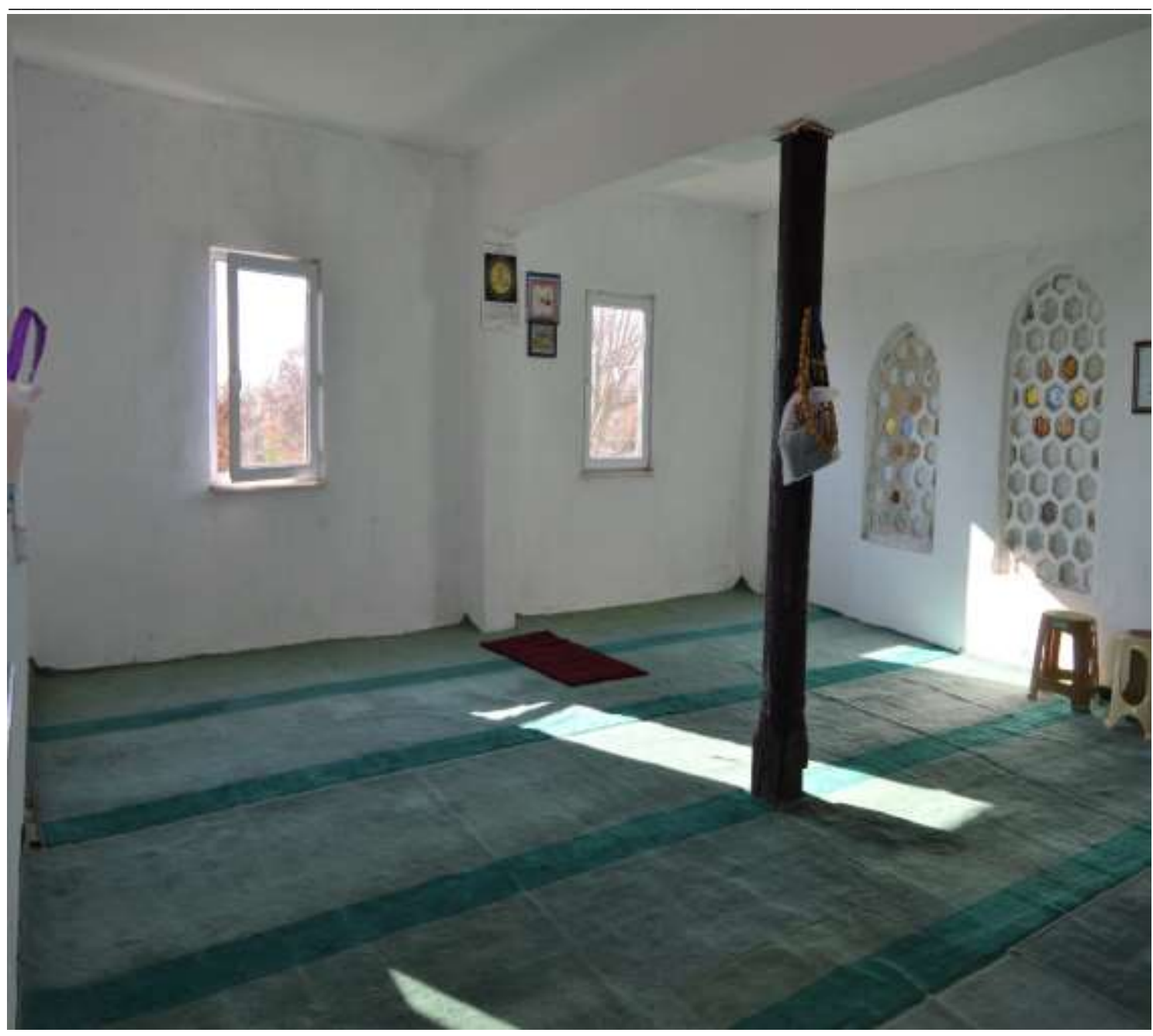

EK-5: Şeyh Hamza türbesinin bitişiğine inşa edilmiş olan mescit. Dış kapıdan mescide girilmekte içerden bir kapıyla da Şeyh Hamza türbesine geçilmektedir. 


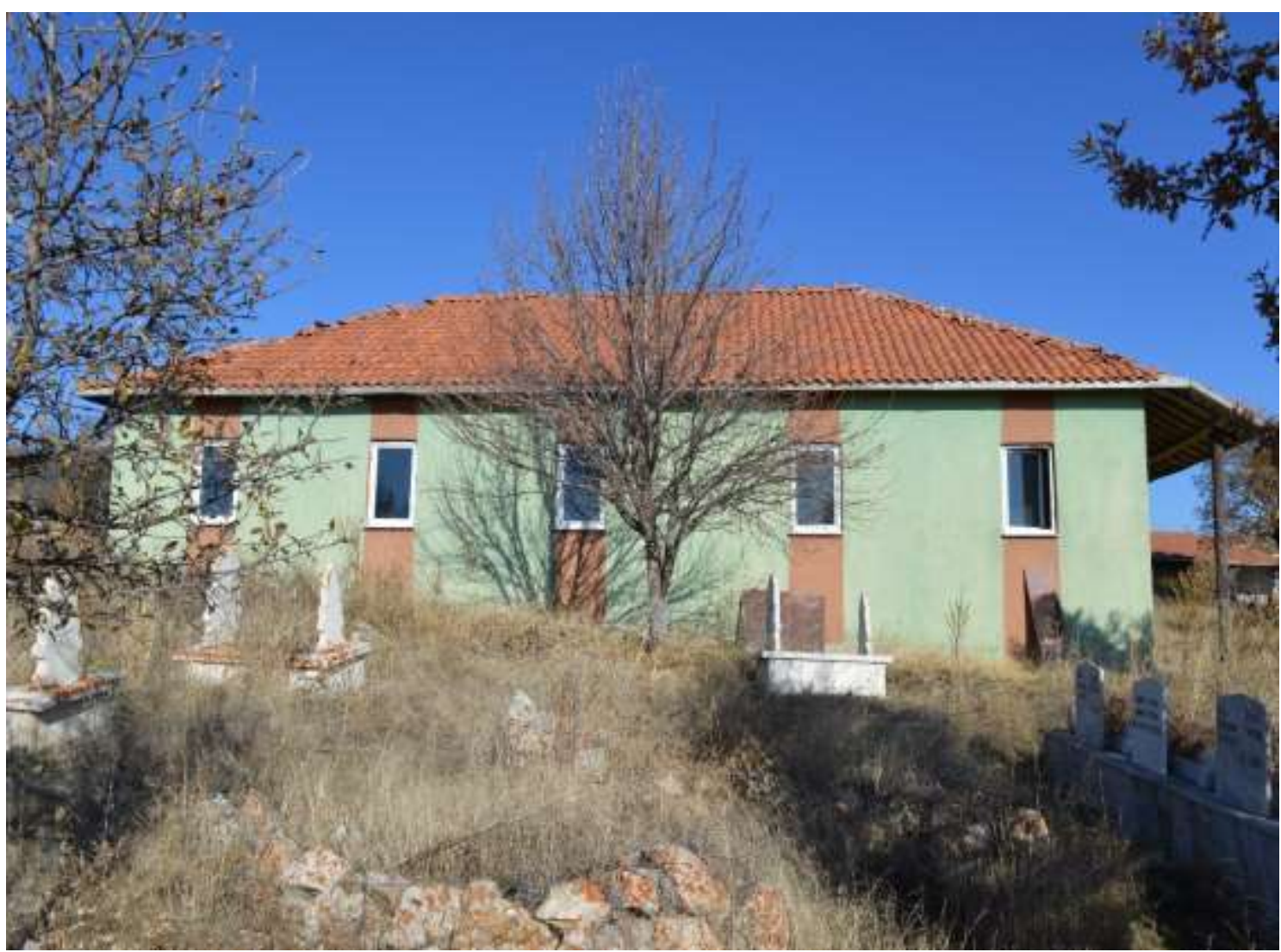

EK-6: 2012 yılında inşa edilen Şeyh Hamza türbesi ve mescidinin bulunduğu yapı. Köy mezarlığı da türbenin etrafında bulunmaktadır.

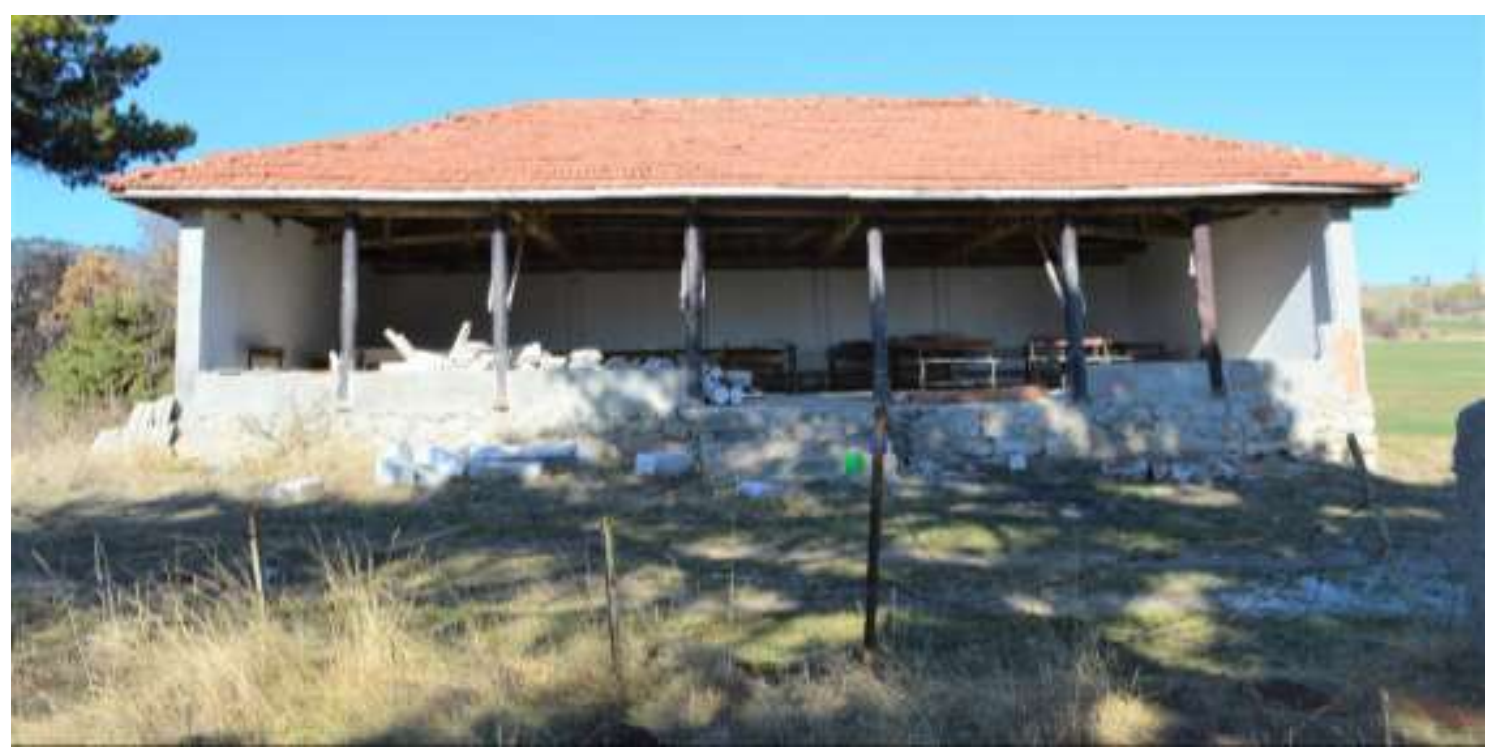

EK-7: Bugün tarihi yapılardan ve imaretten eser kalmamışsa da türbe ziyaretine gelenlerin hizmetine sunulan yap1. 


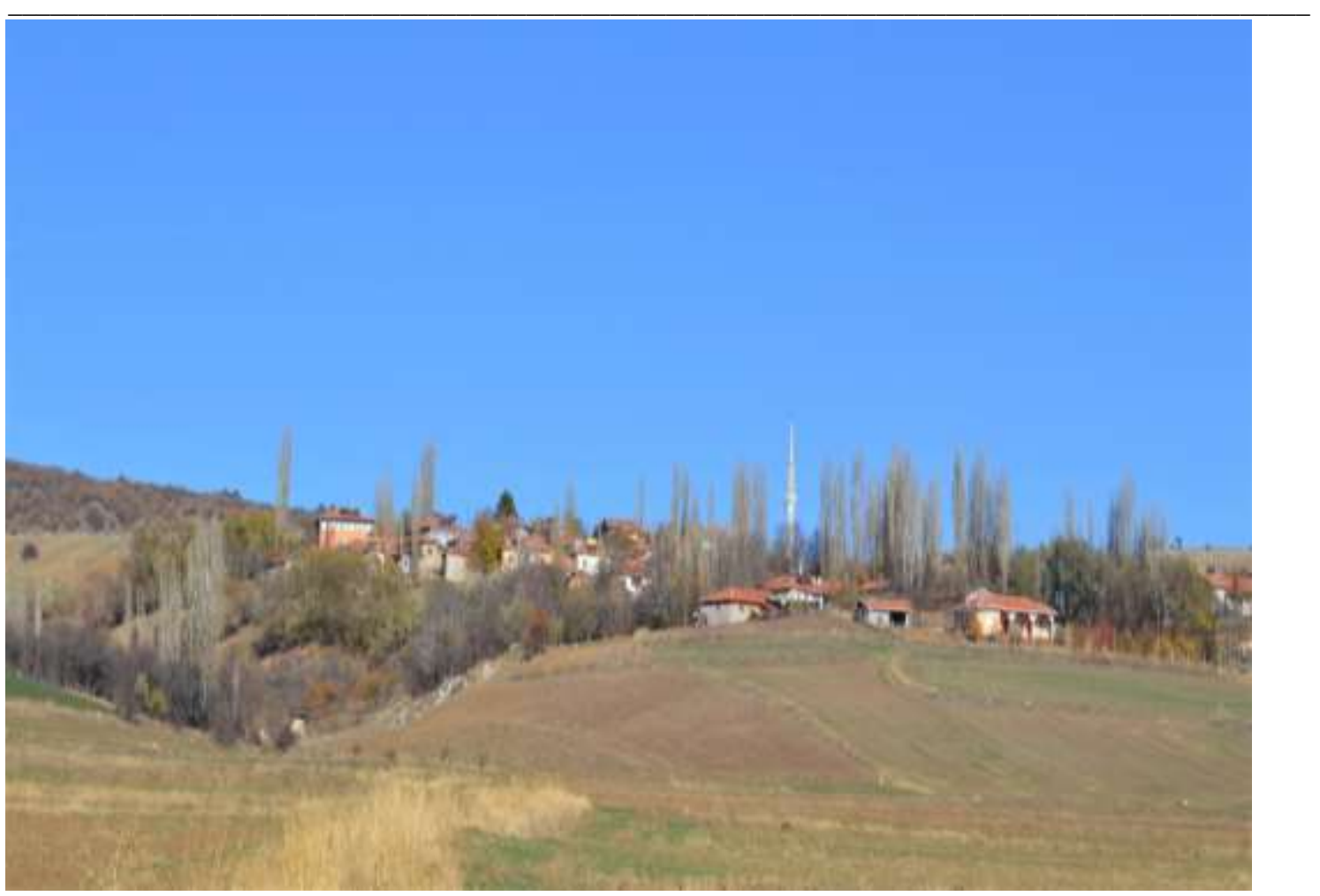

EK-8: Dağl1k bir alanda kurulmuş olan Şeyh Hamza köyünün genel görünümü. 


\section{SUMMARY}

It is not known when exactly Sheikh Hamza has lived. Having lived and died in Hac1 Bey Ağac1 village of Çorum, the burial site of Sheikh Hamza has seemingly disappeared over time. It has been revealed that he was a historic figure with an influence on the religious, social and cultural life of the locals. According to archives, the grave of Sheikh Hamza was found following a divine intervention. It was revealed during a dream to Dervish Hidır residing in Çorum. With the help of the locals, as well as the state officials, Dervish Hidir first found and then built a shrine and a lodge at the burial site. Following the construction of the shrine and lodge, the name of the village was named Sheikh Hamza and this change was reflected in official records. Unlike the earlier ones, this monastery has been revealed at later stages, during mid-18th century and its official recognition and addition into the system also took a great while. The reason for the monastery to gain popularity among the public was its location on the Çorum-Laçin-Osmancık route, which does not include any other similar structures offering the same service. Another factor for this is the strong willingness for both the local community and the state officials, thanks to Dervish Hidir's efforts, to own Sheikh Hamza shrine and lodge. Hence, the donations requested from the central authority for the shrine and lodge have been personally requested by local authorities as a plead of the people of Çorum, which is clear indication of this. Unlike the early-age examples, Sheik Hamza monastery failed to gain rich foundation revenues despite all these efforts and therefore its socio-economic structure was relatively weak. Sheik Hamza shrine received allocations only from Gürcü village of Sivas and such help was intended only for limited needs. The difficult political, military and economic conditions of the state must have had a great impact for ending up with such a consequence. Furthermore, lodges, monasteries and shrines became widespread at the time all around the empire and the foundation revenues allocated to these have also reached high levels. Another factor for it was the weak social relations of Sheikh Hamza lodge.

Another noteworthy issue is that we do not have confirmed data on the sect followed by Sheikh Hamza as well as Dervish Hidir, who helped finding his burial site. However, it is very likely that Dervish Hıdır was a follower of Mawlaviyah, Naqshbandi Khalidiyya or Rifâî sects, who all had a lodge in Çorum in those days. The historic shrine and lodge in Sheikh Hamza village are now all gone but the re-built shrine and masjid is still playing an important role in serving the religious, social and cultural lives of the locals.

The purpose of this study is to reveal the administrative, social and economic structure of Sheikh Hamza shrine and lodge, and to understand the impact on society's faith and minds. This current study has been mostly based on archive documents due to several factors such as the subject being highly specific and narrow and lack of information in secondary resources. With the purpose of making an on-site assessment of Sheikh Hamza and his shrine's geographical location and also to reveal his importance in the eyes of the community, field study methods and techniques have been used. One of the most important conclusions of the study was to clearly reveal some of the administrative and financial difficulties experienced by lodges and monasteries after late 18th century, particularly due to the modernization process at the time. Sheikh Hamza lodge had to struggle for a long time for accreditation and despite all efforts it was not possible to be allocated regular foundation revenue, hence leaving it in a weak socio-economic structure. 